BRAZ, Luciano da Silva. A razão dialética entre o direito e a condição humana: consciência, reconhecimento e emancipação. Revista Eletrônica Direito e Política, Programa de Pós-Graduação Stricto Sensu em Ciência Jurídica da UNIVALI, Itajaí, v.10, n.2, $1^{0}$ quadrimestre de 2015. Disponível em: www.univali.br/direitoepolitica - ISSN 1980-7791.

\title{
A RAZÃO DIALÉTICA ENTRE O DIREITO E A CONDIÇÃO HUMANA: CONSCIÊNCIA, RECONHECIMENTO E EMANCIPAÇÃO
}

\author{
THE REASON DIALETIC BETWEEN RIGHT AND THE HUMAN CONDITION: \\ AWARENESS, RECOGNITION AND EMANCIPATION
}

\section{Luciano da Silva Braz ${ }^{1}$}

SUMÁRIO: Introdução; 1 . A relação dialética entre o direito e a política; 2. A linguagem e o direito: tensão entre facticidade e validade; 3. A função instrumental do agir comunicativo: integração, manutenção e ordem social; 4. Esfera pública \& autodeterminação: ordem e paradoxos; 4.1 Taylor, Honneth e Habermas: pressupostos teóricos para um reconhecimento; 5. Biopolítica, cidadania e reconhecimento; 5.1 Dignidade humana, exercício político e emancipação; 6. Autonomia política, razão discursiva e soberania popular; Considerações finais; Referências das Fontes Citadas.

RESUMO: A proposta de Habermas que busca perquirir a legitimidade do Estado constitucional democrático com base nos direitos humanos visa a estabelecer uma conexão interna entre uma democracia efetiva - exercício político - e o direito. Para tanto, faz-se necessário a formulação de um conceito político de legitimação de ordens caracterizadas pela organização do poder estatal, que segue atrelado ao direito legitimamente instituído. Considerando que esse médium da potência estatal se constitui sob a forma do direito, as ordens políticas buscam, na legitimidade reivindicada do direito, seu vigor. O presente artigo tem como foco de pesquisa examinar o déficit teórico quanto as possibilidades de implementação do exercício democrático, o reconhecimento, bem como, analisar a relação de completitude entre a política e o direito. Dado às realidades dispares situadas no mundo da vida, questiona-se a própria validade do direito quando temas ligados aos direitos fundamentais do homem, sua dignidade e reconhecimento e, a compreensão do Estado Democrático de Direito se contradizem ante realidades que ainda apontam pessoas, grupos, e etnias esquecidas à margem da sociedade. Este esboço é suficiente para levantar o problema típico das sociedades modernas: como estabilizar, na

\footnotetext{
${ }^{1}$ Professores de Direito Constitucional na Universidade do Oeste Paulista - Unoeste -. Advogado. Mestre em filosofia do direito pelo Centro Universitário Eurípides de Marília (UNIVEM), com Bolsa Caps. Graduado no Curso de Direito do Univem. Bolsista pela FAPESP / Iniciação Científica 2008 2009 com deferimento de renovação para 2010. Integrante do Grupo de Pesquisa Científicas BIOÉTICA - UNIVEM - Centro Universitário Eurípides de Marília/SP. Possui cadastro no Grupo de pesquisa - Processos político-sociais e exclusão - Universidade Estadual Paulista "Júlio de Mesquita Filho" Unesp-Marília/SP. Pesquisador com cadastro junto ao CONPEDI - Conselho Nacional de Pesquisa e Pós-Graduação em Direito - desde 2009. brazadvogadoluciano@gmail.com
} 
BRAZ, Luciano da Silva. A razão dialética entre o direito e a condição humana: consciência, reconhecimento e emancipação. Revista Eletrônica Direito e Política, Programa de Pós-Graduação Stricto Sensu em Ciência Jurídica da UNIVALI, Itajaí, v.10, n.2, $1^{0}$ quadrimestre de 2015. Disponível em: www.univali.br/direitoepolitica - ISSN 1980-7791.

perspectiva própria dos atores, a validade duma ordem social legitima do ponto de vista do direito? À vista de tal possibilidade, Habermas buscar envolver-se com o problema central que abarca as possibilidades de reprodução social, à luz das pretensões de validade.

Palavras-Chave: Dignidade Humana; Luta por Reconhecimento; Emancipação; Estado Democrático de Direito.

ABSTRACT: The proposed Habermas seeking to assert the legitimacy of the democratic constitutional state based on human rights aims to establish an internal connection between an effective democracy - political exercise - and the right. Therefore, it is necessary to formulate a political concept of legitimacy of orders characterized by the organization of state power, which follows pegged to the law legitimately established. Whereas the medium of state power is constituted in the form of law, policies seek orders in the legitimacy of the claimed right, its vigor. This article is focus of research examining the theoretical deficit and possibilities for implementation of the democratic exercise, recognition, and to evaluate the completeness of relationship between politics and the law. Given the disparate realities located in the world of life, questions the very validity of the law when issues related to fundamental rights, dignity and recognition and understanding of the democratic rule of law contradict ante realities that still point persons, groups and ethnicities forgotten the margins of society. This sketch is enough to raise the typical problem of modern societies: how to stabilize in the proper perspective of the actors, the validity of a social order legitimizes the point of view of law? In view of this possibility, Habermas seek to engage with the central problem that embraces the possibilities of social reproduction in light of the valid claims.

Keywords: Human Dignity; Struggle for Recognition; Emancipation; Democratic state.

\section{INTRODUÇÃO}

Dentre as principais ideias abordadas nas obras de filosofia política e filosofia do direito apresentadas por Habermas, esse artigo selecionou algumas considerações do filósofo alemão no que diz respeito a temática proposta. Nas primeiras linhas desse artigo, onde trabalhamos a interpretação e a lógica do Estado de Direito procuraremos examinar as figuras do direito e do poder político e, por conseguinte, a interligação complexa que visa a preencher, reciprocamente, as funções que se interligam uma a outra. Destacaremos que a relação entre direito e política diferencia-se da relação entre moral e direito, e a ligação entre a moral e o direito delineia-se numa relação de complementaridade assentada nas esferas de valor que se diferenciam na modernidade. Nesse sentido, identificaremos o aparelho estatal descrito a partir de um sistema organizacional do direito. 
BRAZ, Luciano da Silva. A razão dialética entre o direito e a condição humana: consciência, reconhecimento e emancipação. Revista Eletrônica Direito e Política, Programa de Pós-Graduação Stricto Sensu em Ciência Jurídica da UNIVALI, Itajaí, v.10, n.2, $1^{0}$ quadrimestre de 2015. Disponível em: www.univali.br/direitoepolitica - ISSN 1980-7791.

Herdeiro do hegelianismo (intersubjetividade, evolucionismo dialético) e do kantismo (universalidade, incondicionalidade, formalismo), Habermas quer encontrar razões que justifiquem - por uma obrigação incondicional, objetiva, e por um decreto moral da razão - a conduta democrática para além do caráter contingente de meras preferências ou tendências reguladas e das conversões partilhadas de uma determinada sociedade. A abordagem habermasiana procura formular uma base normativa para alimentar formas democráticas de comunidade, para além do acordo contigente. Essa base, segundo Habermas, pode encontrada nos pressupostos implícitos universais de toda interação comunicativa, dos quais sustentariam ou balizariam uma moralidade política mínima, em última análise, democrática, não regulamentada por esta ou aquela concepção, mas no campo estritamente procedimental. Isso torna central o aspecto da busca de reconhecimento, à qual Habermas dedica parte das suas considerações teóricas contemporâneas.

Dentre os assuntos abordados no corpo deste artigo, analisamos algumas questões voltadas para as perspectivas normativas de reconstrução do sistema dos direitos e dos princípios do Estado de Direito. Aqui, veremos como Habermas compreende os desafios derivados do poder social e da complexidade das sociedades modernas. Arrostamo-nos, então, com uma tensão externa entre fatos sociais e direito, ou seja, entre auto compreensão normativa do Estado de Direito e facticidade social dos processos políticos. O artigo demonstrará a relação de complementaridade entre o direito e a política, bem como, seus pressupostos de validade para regularização da vida social. A questão da legitimação de um poder político estruturado na forma do Estado de Direito, pode ser compreendida desde que, mediante a ótica do conceito de autonomia política dos cidadãos, fundamentado na teoria do discurso, se consiga diferenciar as figuras do poder comunicativo, produto do direito legítimo, e aqueles pertencentes ao poder administrativo, responsável pela imposição das leis. Veremos que as formas comunicativas devem interligar e satisfazer, simultaneamente, a diferentes condições de comunicação, uma vez que, se prescindirmos da organização da afluência dessas informações, poderemos nos valer do auto entendimento ético e da fundamentação moral de regras com a finalidade de estabelecermos o equilíbrio equitativo de interesses.

\section{A RELAÇÃo diALÉtiCA ENTRE O DIREITO E A POLÍtICA}

O direito em sua função estabilizadora apresenta-se como um sistema de direitos. Dado esse pressuposto, entende-se que os direitos subjetivos só podem ser estatuídos e impostos a partir de organismos que tomam decisões de caráter obrigatório para toda coletividade. Com isso temos a figura dos direitos fundamentais que trazem em sua essência ameaças e sanções que podem ser usados contra interesses opostos ou transgressões de normas que surripiam o 
BRAZ, Luciano da Silva. A razão dialética entre o direito e a condição humana: consciência, reconhecimento e emancipação. Revista Eletrônica Direito e Política, Programa de Pós-Graduação Stricto Sensu em Ciência Jurídica da UNIVALI, Itajaí, v.10, n.2, $1^{0}$ quadrimestre de 2015. Disponível em: www.univali.br/direitoepolitica - ISSN 1980-7791.

direito a iguais liberdades subjetivas. Esses direitos pressupõem o poder de sanção de um órgão legalmente revestido, o qual dispõe de meios para o emprego legítimo da coerção para impor o acatamento, a submissão às normas jurídicas. O nexo interno do direito com o poder político reflete nas implicações objetivas e jurídicas estampadas na figura do Estado que mantém como reserva um poder militar, a fim de garantir seu poder de comando ${ }^{2}$. A pretensão a iguais direitos, numa comunidade de membro (livres) do direito, segundo Habermas, pressupõe uma coletividade limitada no espaço e no tempo, de forma que esses direitos asseguram a todos os membros dessa comunidade um reconhecimento recíproco, ou seja, eles se identificam como sujeitos de direitos, em outras palavras, há o reconhecimento dum status de direito conferido a todos em comum, de forma que eles podem imputar suas ações como partes do mesmo contexto de interações. Com suas palavras, Habermas ${ }^{3}$ se expressa na seguinte forma:

A reconstrução proposta da conexão entre os direitos de liberdade e os civis parte de uma situação na qual, como queremos admitir, cidadãos livres e iguais pensam em conjunto como podem regulamentar a sua vida em comum tanto por meio do direito positivo como também de modo legítimo (...). Esse modelo inicia-se com as relações horizontais dos cidadãos uns com os outros e introduz as relações dos cidadãos com o aparato estatal, necessários em termos funcionais, apenas em segundo passo, portanto já com base no direito fundamental já existente.

Essas considerações tangem sustentar a autoafirmação sob a qual o Estado instaura sua capacidade para a organização e a auto-organização que buscar assegurar e manter - tanto no aspecto interno como no externo - a identidade da convivência juridicamente organizada.

O direito fundamental ratifica a cada cidadão o direito à proteção jurídica individual, de forma que as pretensões a uma justiça independente e imparcial nos julgamentos passam ser corolário do Estado de Direito. O direito - como expressão da soberania estatal e tendo nesta seu único foco irradiador - resulta num instrumento de gestão da sociedade que busca dar segurança e garantia aos cidadãos. Com fundamento na soberania estatal é posto um conjunto de normas jurídicas que regulam a efetivação dos direitos e garantias. Esse conjunto é conservado, aplicado e, a todo momento, modificado ${ }^{4}$. Assim, a instalação de um tribunal organizado politicamente assevera em cada julgamento

\footnotetext{
2 HABERMAS, Jürgen. Mudança estrutural da esfera Pública. 2. ed. Tradução: Flávio R. Kothe. Rio de Janeiro: Tempo Brasileiro. 2003, p. 170.

3 HABERMAS, Jürgen. A constelação pós-nacional: Ensaios políticos. Tradução: Márcio Seligmann Silva. São Paulo: Littera Mundi, 2001, p. 153-154.

${ }^{4}$ POZZOLI, Lafayette. Maritain e o Direito. São Paulo: Loyola. 2001, p. 163.
} 
BRAZ, Luciano da Silva. A razão dialética entre o direito e a condição humana: consciência, reconhecimento e emancipação. Revista Eletrônica Direito e Política, Programa de Pós-Graduação Stricto Sensu em Ciência Jurídica da UNIVALI, Itajaí, v.10, n.2, 10 quadrimestre de 2015. Disponível em: www.univali.br/direitoepolitica - ISSN 1980-7791.

o poder de sanção do Estado, pretendendo proteger e desenvolver o direito nos casos litigiosos, onde se faz mister uma decisão autoritária aplicada pelo Estado (juiz). A positivação política autônoma do direito, garantida a partir de um direito legitimamente instituído, concretiza-se em direitos fundamentais dos quais (surgem), asseguram condições para iguais pretensões à participação em processos legislativos democráticos, que demandam o exercício do poder político devidamente (legalmente) instituído. Além disso, o Estado, no seu exercício burocrático de dominação legal, faz valer concretamente a formação da vontade política que se organiza na forma do legislativo e, para tanto, conta diretamente com o poder executivo em condições de realizar e implementar os programas acordados. A presença do Estado no seu caráter de jurisdição - tanto administrativa como judicial - dependem da medida em que a sociedade se vale do médium do direito para influir conscientemente em seus processos de reprodução. Com isso, fala-se na dinâmica da auto influência, acelerada por meio dos direitos de participação que fundamentam pretensões ao preenchimento dos pressupostos sociais, culturais e ecológicos úteis para o aproveitamento simétrico de direitos particulares de liberdade e de participação na vida política. 5. Em síntese, o Estado é necessário como poder de organização, de sanção e de execução, porque os direitos têm que ser implantados, porque a comunidade de direitos necessita de uma jurisdição organizada e de uma força para estabilizar a identidade, e porque a formação da vontade política cria programas que têm que ser implementados. Tais aspectos não constituem meros complementos, funcionalmente necessários para o sistema de direitos, e sim, implicações jurídicas objetivas, contidas in nuce nos direitos subjetivos ${ }^{6}$. O poder organizado politicamente não se aproxima do direito como algo que the seja externo, pelo contrário, é pressuposto pelo direito; em outras palavras, o poder político organizado se estabelece em formas do direito. Nesse sentido, o poder político só pode desenvolver-se mediante a constituição de um código jurídico institucionalizado em conformidade com os direitos fundamentais. No Estado de Direito, as decisões coletivamente obrigatórias são implantadas mediante o poder político organizado que o direito precisa tomar para a realização das suas funções próprias; não se revestem apenas a forma do direito, essas decisões devem - também - ser legitimadas pelo direito corretamente estatuído. As formações discursivas da opinião e da vontade figuram como premissas fundamentais para legitimidade do direito, ou seja, dentro do pensamento póstradicional, só vale como legítimo o direito que fora elaborado no interior de uma comunidade democrática que, utilizando do discurso racional, convenciona, normas reconhecidas reciprocamente pelos sujeitos. Consequentemente, institui-

\footnotetext{
${ }^{5}$ SILVA, Luciano Braz. Legitimidade do poder e exercício político: facticidade e validade do direito. Perpectivas para uma análise normativa e instrumental. EM TEMPO - Marília - v. 12 - 2013, p. 224.

${ }^{6}$ HABERMAS, Jürgen. Era das transições. Tradução: Flávio BenoSiebeneichler. Rio de Janeiro: Tempo Brasileiro, 2003, p. 171.
} 
BRAZ, Luciano da Silva. A razão dialética entre o direito e a condição humana: consciência, reconhecimento e emancipação. Revista Eletrônica Direito e Política, Programa de Pós-Graduação Stricto Sensu em Ciência Jurídica da UNIVALI, Itajaí, v.10, n.2, 10 quadrimestre de 2015. Disponível em: www.univali.br/direitoepolitica - ISSN 1980-7791.

se a incorporação do exercício da autonomia política dos cidadãos em toda esfera do Estado - a legislação é reconhecida como um poder no Estado ${ }^{7}$. A transação dos direitos reciprocamente atribuídos na via da socialização horizontal pelos civis para formas verticais de organização socializadora faz com que a prática de autodeterminação dos civis seja institucionalizada - como formação informal da opinião na esfera pública política, como participação política no interior e no exterior dos partidos, como participação em votações gerais, na consulta e tomada de decisão de corporações parlamentares, etc ${ }^{8}$. Com efeito, a soberania popular interliga-se internamente com as liberdades subjetivas do civis, a mesma, por seu turno entrelaça-se com o poder politicamente organizado, de modo que o princípio "todo o poder político emana do povo", paulatinamente, concretiza-se por meio de procedimentos e pressupostos comunicativos de uma formação institucionalmente diferenciada da opinião e da vontade.

No Estado de Direito delineado por regras da teoria do discurso, a soberania do povo não se encerra mais numa coletividade de cidadãos autônomos facilmente identificáveis. A soberania popular instala-se nos círculos de comunicação de foros e corporações destituídos de sujeitos determinados. Portanto, dado o anonimato, seu poder comunicativo diluído pode entrelaçar ao poder administrativo do aparelho estatal à vontade dos cidadãos. Nesse sentido, destaca Habermas ${ }^{9}$ que, no Estado de Direito democrático, o poder político diferencia-se em poder comunicativo e administrativo. Tratando-se da correlação estante na vinculação interna entre política e direito, a tensão entre facticidade e validade, no Estado Democrático de Direito, estende-se ao âmbito do próprio poder político. A política com seu domínio, por um lado, vale-se da potencial ameaça fundada pela força da "caserna" e, por conseguinte, deve estar autorizada do ponto de vista do direito legítimo. Isso significa dizer que a dominação política deve espelhar a imagem do poder legitimado e organizado do ponto de vista jurídico, de modo que não se pode distanciar da perspectiva moderna, a qual entende que a legitimidade do poder, necessariamente, deve estar revestida pelo manto da legalidade.

Entende-se que o exercício do poder na forma do direito não deve ser deslocado do momento de sua fundamentação. Essa preocupação consiste exatamente em reconstruir a constituição cooriginária entre poder político e o direito, mostrando que, mediante essa relação, resulta um novo nível da tensão entre facticidade e validade, agora situada no próprio poder político, a questão da legitimação de um poder político estruturado na forma do Estado de Direito pode ser compreendida desde que, por intermédio da ótica do conceito de autonomia

\footnotetext{
7 SILVA, Luciano Braz. A função do direito no mundo da vida: LINGUAGEM, EMANCIPAÇÃO E RECONHECIMENTO. Revista Direito e Liberdade - Santa Catarina - v. 15, n. 3, 2013, p. 81.

${ }^{8}$ HABERMAS, Jürgen. Era das transições, p. 173.

${ }^{9}$ HABERMAS, Jürgen. Era das transições, p. 173.
} 
BRAZ, Luciano da Silva. A razão dialética entre o direito e a condição humana: consciência, reconhecimento e emancipação. Revista Eletrônica Direito e Política, Programa de Pós-Graduação Stricto Sensu em Ciência Jurídica da UNIVALI, Itajaí, v.10, n.2, $1^{0}$ quadrimestre de 2015. Disponível em: www.univali.br/direitoepolitica - ISSN 1980-7791.

política dos cidadãos. Para Aluisio Schumacher ${ }^{10}$, a contribuição do poder político para a função intrínseca do direito (estabilizar expectativas de comportamento) consiste na geração de uma certeza jurídica, que possibilita aos destinatários do direito calcular as consequências de seu comportamento e dos outros. As normas jurídicas, em termos gerais, devem regular as circunstâncias, as situações de fato, aplicando a sua subsunção de forma imparcial. Esses requisitos são compreendidos à luz de uma codificação (atividade jurisprudencial), que proporciona normas jurídicas altamente consistentes.

Com relação ao direito, sua contribuição à função intrínseca do poder administrativo (realizar fins coletivos) evidencia-se, especialmente, no desenvolvimento de normas secundárias, que, segundo Schumacher, não se tratam tão-somente daquelas normas que conferem poder (e até criam) às instituições governamentais dotando-as de jurisdições especiais, como também normas organizacionais que estabelecem procedimentos para a existência e gestão administrativa ou judicial de programas jurídicos. Assim, a atividade do direito, sua função e aplicabilidade, atinge outras esferas que não somente a da atividade jurisprudência jurídica, mas alcança também a esfera das instituições de governo - procedimentos e competências - garantindo, assim, a autonomia privada e pública dos cidadãos. ${ }^{11}$

\section{A LINGUAGEM E O DIREITO: TENSÃO ENTRE FACTICIDADE E VALIDADE}

Na sociedade moderna, mormente os sistemas sociais, de forma objetiva, tendem a regularizar os fatos que surgem no mundo da vida e, para tanto, impõem exigências que visam prover a manutenção das ordens sociais então existentes. Característica da sociedade moderna, os sistemas sociais apontam dois atores que dividem o protagonismo a tal fim que, desde o século passado, vem contribuindo, consideravelmente, para a colonização do mundo da vida ${ }^{12}$.

Dadas as figuras predominantes da política e do mercado, o sistema econômico, destacado pelos liberais, confronta-se com objetivos e ideologias traçados pelos social-democratas que buscam compensar a preponderância econômica com as

10 SCHUMACHER, Aluisio Almeida. "Comunicação e democracia: fundamentos pragmáticoformais e implicações jurídico-políticas da teoria da ação comunicativa". 2000. 245 f. Tese (Doutorado em Ciências Política). Departamento de Ciências Política do Instituto de Filosofia e Ciências Humanas da Universidade Estadual de Campinas. Campinas, 2000, p. 245.

11 SCHUMACHER, Aluisio Almeida. "Comunicação e democracia: fundamentos pragmáticoformais e implicações jurídico-políticas da teoria da ação comunicativa", p. 245.

12 Habermas define o mundo da vida, como o horizonte de conviç̧ões comuns e indubitáveis, que possibilita um conhecimento familiar dos participantes da interação linguística. O mundo da vida é em outras palavras, um bloco de modelos consentidos de interpretação, de lealdade e práticas. HABERMAS, Jürgen. Pensamento pós-metafísico: estudos filosóficos. Trad. Flávio BenoSiebeneichler. Rio de Janeiro: Tempo Brasileiro, 1990, p. 95 
BRAZ, Luciano da Silva. A razão dialética entre o direito e a condição humana: consciência, reconhecimento e emancipação. Revista Eletrônica Direito e Política, Programa de Pós-Graduação Stricto Sensu em Ciência Jurídica da UNIVALI, Itajaí, v.10, n.2, 10 quadrimestre de 2015. Disponível em: www.univali.br/direitoepolitica - ISSN 1980-7791.

intervenções do sistema político. A proposta fomentada pela escola do liberalismo aponta para uma competição de mercado livre e independente, como fator de regulação social, o que, por conseguinte, resulta em desigualdades materiais entre os indivíduos, assim como na monopolização e na duradoura crise da economia de mercado. No entanto, a proposta trazida pelos ideários do estado de bem-estar social, que buscam concretizar no mundo da vida - por meio do controle de mercado - a igualdade material fomentada pela intervenção do sistema político no mundo da vida, não obstante os desarranjos e transtornos burocráticos a serem resolvidos. O Estado liberal e o Estado de bem-estar confrontam-se reciprocamente, o que, de certa forma, prejudica, desestabilizando a manutenção da ordem social no seu todo e, por conseguinte, faz suscitar, no espírito da sociedade, uma descrença a uma possível estabilidade social. Dada descrição da sociedade moderna, o médium do direito apresenta-se como um instrumento - especialmente na figura moderna do direito positivo - de colonização do mundo da vida, na medida em que as relações sociais cotidianas e familiares estão a cada dia mais impregnadas pela "juridificação". ${ }^{13}$

As discussões em torno do conceito de direito, de sistema de direitos e de Estado Democrático de Direito permitiram inserir um elemento intermediário entre a solidariedade da ação comunicativa no mundo da vida e a instrumentalidade dos sistemas que operam estrategicamente. Destarte o direito, via sistema jurídico, representa o instrumento pelo qual opera o intercâmbio entre o mundo da vida e os sistemas, bem como entre ação comunicativa e estratégica. A partir do conceito do agir comunicativo - em que encontramos forças ilocucionárias da linguagem orientada ao entendimento - podemos visualizar - no próprio conceito - sua função peculiar e necessária à coordenação da ação. Para Habermas ${ }^{14}$, a tensão entre facticidade e validade, que se introduz no próprio modo de coordenação da ação, coloca exigências elevadas para a manutenção de ordem social. Portanto, torna-se indiscutível que, tanto o mundo da vida como também as instituições que surgem naturalmente, e o próprio direito, têm que aniquilar as instabilidades de um tipo de socialização que se estrutura e se realiza com as tomadas de posição em termos de sim e de não, que seguem instauradas em face de pretensões de validade criticáveis. Isso explica, de um lado, a estrutura e o sentido de validade de direitos subjetivos e, de outro lado, as conotações idealistas de uma comunidade jurídica que, enquanto associação de cidadãos livres e iguais, determina por si mesma as regras de sua convivência.

À vista dos sistemas sociais que integram o mundo da vida, a sociedade moderna, marcada pelo pluralismo, multiculturalismo e, sobretudo, a

13 DURÃO, Aylton Barbieri. A tensão interna entre facticidade e validade no direito segundo Habermas. (Org), MARTINS, Clélia Aparecida, e POKER, José Geraldo. O pensamento de Habermas em questão. Marília: Oficina Universitária Unesp, 2008, p. 15.

${ }^{14}$ HABERMAS, Jürgen. Mudança estrutural da esfera Pública, p. 25-26. 
BRAZ, Luciano da Silva. A razão dialética entre o direito e a condição humana: consciência, reconhecimento e emancipação. Revista Eletrônica Direito e Política, Programa de Pós-Graduação Stricto Sensu em Ciência Jurídica da UNIVALI, Itajaí, v.10, n.2, $1^{0}$ quadrimestre de 2015. Disponível em: www.univali.br/direitoepolitica - ISSN 1980-7791.

complexidade emergente, revela-se no papel preponderante do direito, no que diz respeito à sua função social integradora. Dada perspectiva, entende-se que o direito funciona como um instrumento que regula e integra o mundo social, bem como as relações que ocorrem nesse campo. Dado seu caráter transformador atuante no campo das reivindicações suscitadas no mundo da vida - comumente expressas em linguagens habituais do cotidiano segundo a racionalidade comunicativa e a racionalidade estratégica dos sistemas sociais -, o direito oferece aos sujeitos duas vias que podem ser utilizada a pretexto da finalidade das suas reivindicações. Por um lado, temos a figura da solidariedade da ação comunicativa atuante no mundo da vida; por outro, temos a figura da lei que, mediante seu poder coercitivo, regula as ações dos sujeitos que atuam na esfera do mundo social. Considerando a função social integradora que o direito exerce, a mesma não pode ser realizada tão-somente pelo entendimento inerente ao mundo da vida, tampouco pelos sistemas funcionais reguladores, sobretudo o sistema econômico e político especializados na racionalidade estratégica. Habermas vê, na figura do direito positivo moderno, a possibilidade de assimilar - via ação comunicativa - a tensão entre facticidade e validade. À vista de tal possibilidade busca envolver-se com o problema central que abarca as possibilidades de reprodução social, à luz das pretensões de validade. A explicação poder-se-ia apresentar a partir do direito moderno, onde:

(...) uma vez que, segundo sua mediação, faz-se possível o surgimento de comunidades artificiais, comunidades jurídicas (sociedades mercantis, Estados federativos, comunidades internacionais, etc.), que, por sua vez, se compõem de membros livres e iguais, cuja sociabilidade resulta de uma pretensa ameaça de sanção e da suposição de um acordo racional a lhe dar fundamento. ${ }^{15}$

Precisamente, essa é a razão pela qual Habermas considera que o conceito do agir comunicativo atribui às forças ilocucionárias da linguagem orientada ao entendimento a função importante da coordenação da ação. Os atos ilocucionários trazem, em seu bojo, por meio da força comunicativa do enunciado, a execução de uma ação; daí, conclui-se a vinculação entre agir comunicativo e a força dos atos ilocucionários da qual, a partir desse patamar, se poderá delinear uma nova relação entre facticidade e validade por meio do médium linguístico. ${ }^{16}$

Não obstante a transição da razão prática para a ação comunicativa possa significar uma ruptura com a tradição normativa, a filosofia de Habermas não descarta as preocupações de ordem fundamental que tratam dos problemas que assolam o mundo da vida. Por um lado, temos a estrutura e o sentido de

15 MOREIRA, Luiz. Fundamentação do direito em Habermas. Belo Horizonte: Mandamentos, 1999 , p. 113.

${ }^{16}$ MOREIRA, Luiz. Fundamentação do direito em Habermas, p. 114. 
BRAZ, Luciano da Silva. A razão dialética entre o direito e a condição humana: consciência, reconhecimento e emancipação. Revista Eletrônica Direito e Política, Programa de Pós-Graduação Stricto Sensu em Ciência Jurídica da UNIVALI, Itajaí, v.10, n.2, $1^{0}$ quadrimestre de 2015. Disponível em: www.univali.br/direitoepolitica - ISSN 1980-7791.

validade dos direitos subjetivos; por outro, temos as conotações idealistas de uma comunidade jurídica (ideal de fala) e, por tratar-se de uma associação constituída por cidadãos livres e iguais, essa comunidade determina, por si mesma, as regras de sua convivência. Ora, a sociedade moderna, dentre outras características que Ihes são peculiares, traz destacado, em sua identidade, o multiculturalismo ideológico pluralista, o que suscita indagações quanto à possibilidade (ou não) de se coordenar, entre si, os planos de ações dos vários sujeitos, de tal modo que as ações de um partido (atores) possam estar atreladas (relacionadas) nas práticas do outro ${ }^{17}$

Habermas considera que o possível entrelaçamento contínuo reduz o jogo das possibilidades de escolha, duplamente contingente, a uma medida que possibilita o entrelaçamento menos conflituoso possível de intenções e ações, portanto o surgimento de padrões de comportamento e da ordem social no geral. A par disso, temos, ainda, a tarefa de esclarecer a questão de como a razão comunicativa faz a mediação com os fatos sociais e, mais ainda, em que sentido a razão comunicativa poderia incorporar-se aos fatos sociais? Fugindo ao risco de não confundir razão e realidade, Habermas procura demonstrar que a tensão entre facticidade e validade, inerente à linguagem, migra desta para o direito; enquanto a linguagem é utilizada apenas como médium para transmissão de informações e redundâncias, a coordenação ocorre por meio da influenciação recíproca de atores que agem uns sobre os outros de modo funcional. Portanto, tão logo, porém, as forças ilocucionárias das ações de fala assumem um papel coordenador da ação, a própria linguagem passa a ser explorada como fonte primária da integração social. É nisso que consiste o agir comunicativo. ${ }^{18}$

A partir das proposições lógicas inseridas no contexto de fala, os sujeitos, na qualidade de falantes e ouvintes, tentam ajustar - a partir dum acordo de fala racional - interpretações comuns, formuladas com o foco no contexto da fala e com a finalidade de harmonizar entre si seus respectivos planos, via processo de entendimento, pelo caminho de uma busca incondicionada de fins ilocucionários. Sendo assim, no instante que os sujeitos de fala suspendem o enfoque objetivador de um observador e de um agente interessado imediatamente no próprio sucesso, e passam a incorporar um enfoque performativo de um falante que busca entender-se como uma segunda pessoa sobre algo no mundo, as energias de ligação da linguagem podem ser impulsionadas (mobilizadas) para a coordenação de planos de ação. Partindo dessas proposições lógicas de atos de fala, exposições ilocucionárias de atos de fala podem visar a um efeito performativo na ação, ou seja, da resposta afirmativa do destinatário a uma oferta séria, consequentemente, resultam obrigações que se tornam relevantes

17 SILVA, Luciano Braz. Legitimidade do poder e exercício político: facticidade e validade do direito, p. 223-225.

${ }^{18}$ HABERMAS, Jürgen. Mudança estrutural da esfera Pública, p. 36. 
BRAZ, Luciano da Silva. A razão dialética entre o direito e a condição humana: consciência, reconhecimento e emancipação. Revista Eletrônica Direito e Política, Programa de Pós-Graduação Stricto Sensu em Ciência Jurídica da UNIVALI, Itajaí, v.10, n.2, $1^{0}$ quadrimestre de 2015. Disponível em: www.univali.br/direitoepolitica - ISSN 1980-7791.

para as consequências da ação. Surge, assim, a vinculação entre agir comunicativo e a força dos atos ilocucionários e, a partir dessas premissas, se poderá delinear uma nova relação entre facticidade e validade por meio do médium linguístico. Muito embora a migração da razão prática para a ação comunicativa possa representar uma ruptura com a tradição normativista, os problemas que desestabilizam o mundo da vida não foram ignorados por Habermas, isto é, o filósofo procurou considerar como de ordem fundamental tais problemas. Vejamos que, com a colocação do problema da idealização inevitável realizada pela linguagem, idealização que se dá com o entendimento mútuo, surge o perigo de confundir razão e realidade. Sendo assim, dado o fato da razão comunicativa estar adscrita às realidades sociais, devemos responder à questão de como se dará a mediação entre razão comunicativa e fatos sociais ou, em que sentido, a razão comunicativa poderia incorporar-se aos fatos sociais. ${ }^{19}$

Ao que nos parece, a intenção de Habermas $^{20}$ é demonstrar como a tensão entre facticidade e validade, inerente à linguagem, migrará desta para o direito. Esse problema suscitado, no contexto do século $X X$, se dá com a recusa da resposta psicológica aos problemas lógicos e matemáticos e aqueles pertencentes à gramática:

A partir do momento em que as ideias sobre a oposição abstrata entre o inteligível e o fenomenal, que serviam de pano de fundo à metafísica kantiana, não convenciam mais ninguém e, a partir do momento em que o entrelaçamento especulativo e dialético entre as esferas da essência e da aparência, criado por Hegel, perdeu sua plausibilidade, entraram em cena, no decorrer do século XIX, interpretações empiristas que passaram a dar preferência a uma explicação psicológica das relações lógicas ou conceituais: contextos de validade foram assimilados a processos fáticos de consciência. Contra tal psicologismo levantaram-se, utilizando quase sempre os mesmos argumentos, Ch. S. Peirce, na América, Gottlob Frege e Edmund Husserl, na Alemanha, e G. E. Moore e B. Russel na Inglaterra. $\mathrm{E}$, ao se recusarem a tomar a psicologia como base para a lógica, a matemática e a gramática, eles lançaram as bases para a filosofia do século XX.

Para Habermas, esse movimento encontra-se resumido na tese de Frege, ao se procurar diferenciar pensamento e representação. A crítica à opinião, segundo a qual o pensamento não é mais do que consciência representadora, repousa nessa consideração simples. Nas representações, o que temos tão somente são os objetos, sendo que, por outro lado, estado de coisas ou fatos são apreendidos

${ }^{19}$ HABERMAS, Jürgen. Mudança estrutural da esfera Pública, p. 26-27.

${ }^{20}$ HABERMAS, Jürgen. Mudança estrutural da esfera Pública, p. 27. 
BRAZ, Luciano da Silva. A razão dialética entre o direito e a condição humana: consciência, reconhecimento e emancipação. Revista Eletrônica Direito e Política, Programa de Pós-Graduação Stricto Sensu em Ciência Jurídica da UNIVALI, Itajaí, v.10, n.2, $1^{0}$ quadrimestre de 2015. Disponível em: www.univali.br/direitoepolitica - ISSN 1980-7791.

em pensamentos. Logo, pensamentos e fatos devem ser mediados no mundo dos objetos representáveis, de modo a tornar-se possível o aprendizado; eles só são acessíveis (pensamentos e fatos) enquanto representados em estados de coisas expressos por meio de proposições.

Os pensamentos - dado o fato de ultrapassarem os limites de uma consciência individual - articulam-se por meio de proposições assertivas, torna-se, então, possível lermos a estrutura dos pensamentos observando a estrutura das proposições, consideradas por Habermas, como partes elementares de uma linguagem gramatical passíveis de verdade. Nisso, consiste a tese habermasiana de que as expressões linguísticas tenham significado idêntico para os mais diversos usuários $^{21}$. Dessa forma, certamente, em uma dada comunidade de linguagem ocorrerá uma mesma compreensão sobre uma certa expressão gramatical. Nas mais diversas situações em que são empregadas, essas expressões conservam o mesmo significado. Isso quer dizer que, ao serem empregadas, as expressões compartilham de uma certa transcendência que Ihes é peculiar ${ }^{22}$. Na prática, Habermas ${ }^{23}$ considera que, necessariamente, os membros de determinada comunidade de linguagem devem considerar que falantes e ouvintes podem compreender uma expressão gramatical de modo idêntico, para tanto, devem julgar que as mesmas expressões conservam igual significado independente da variedade de situações e dos atos de fala nos quais são empregadas. Assim,

A idealidade, apoiada em sinais linguísticos e regras gramaticais, caracteriza um pensamento geral, idêntico consigo mesmo, aberto e acessível, algo transcendente em relação à consciência individual, não se confundindo com as representações particulares, episódicas, acessíveis apenas privadamente ou imanente à consciência.

A partir desse raciocino lógico gramatical, são concebidas regras que emprestam formas determinadas a eventos linguísticos, numa relação fonética, sintática e semântica, reconhecíveis e solidificadas por meio das variações. No tocante a isso consiste a relação entre o geral e o particular, ou, seguindo a tradição, entre essência e aparência. Sendo assim, a idealidade pressuposta no pensamento aponta a generalidade que se faz transcender à consciência individual, ao que, por conseguinte, não obstante a variedade de vozes abertas e acessíveis existentes no mundo de fala preserva-se um elo condutor opondo-se ao acesso das representações de uma consciência individual particular solipsista.

${ }^{21}$ SILVA, Luciano Braz. A função do direito no mundo da vida: LINGUAGEM, EMANCIPAÇÃO E RECONHECIMENTO, p. 74-75.

${ }^{22}$ MOREIRA, Luiz. Fundamentação do direito em Habermas, p. 116.

${ }^{23}$ HABERMAS, Jürgen. Mudança estrutural da esfera Pública, p. 29. 
BRAZ, Luciano da Silva. A razão dialética entre o direito e a condição humana: consciência, reconhecimento e emancipação. Revista Eletrônica Direito e Política, Programa de Pós-Graduação Stricto Sensu em Ciência Jurídica da UNIVALI, Itajaí, v.10, n.2, $1^{0}$ quadrimestre de 2015. Disponível em: www.univali.br/direitoepolitica - ISSN 1980-7791.

\section{A FUNÇÃO INSTRUMENTAL DO AGIR COMUNICATIVO: INTEGRAÇÃO, MANUTENÇÃO E ORDEM SOCIAL}

O conceito habermasiano do agir comunicativo, que estabelece o entendimento linguístico como premissa fundamental para o mecanismo de coordenação da ação, faz com que as suposições contrafactuais dos atores, que orientam seu agir por pretensões de validade, adquiram relevância imediata para a construção e a manutenção das ordens sociais. Com isso, Habermas pretende demonstrar como a tensão entre facticidade e validade - inerente à linguagem - está pragmaticamente interligada (simbiose) com a integração de indivíduos socializados comunicativamente. Do entendimento linguístico sucede a manutenção das ordens sociais subjacente ao reconhecimento de pretensões de validade normativa que, advém da ligação dos atos ilocucionários de fala reconhecidos mutuamente.

Ao postulado da concretizada ordem social, corolário do entendimento mútuo, liga-se a integração social, predicado este compreendido como a solução do seguinte problema: como é possível coordenar entre si os planos de ação de vários atores, de tal modo que as ações de um partido possam ser "engatadas" nas do outro? A integração social é, assim, descrita pelo "engate" das múltiplas perspectivas de ação, de modo que tais perspectivas possam ser resumidas em ações comuns, ou seja, restringem-se às possibilidades de escolha e, consequentemente, aos possíveis conflitos.

Tal engate contínuo reduz o jogo das possibilidades de escolha, duplamente contingentes, a uma medida que possibilita o entrelaçamento menos conflituoso possível de intenções e ações, portanto o surgimento de padrões de comportamento e da ordem social em geral. Enquanto a linguagem é utilizada apenas como médium para a transmissão de informações e redundâncias, a coordenação da ação passa por meio da influenciação recíproca de atores que agem uns sobre os outros de modo funcional. ${ }^{24}$

Além disso, no ato de integração social, as diversas perspectivas de comportamento são direcionadas para um fim comum que possibilita, concomitantemente, tanto a realização de uma determinada ação como também sua mobilização para um status do qual venha a ser gerada uma adesão. Porém, tão logo as forças ilocucionárias das ações de fala assumem um papel regulador na ação, a própria linguagem passa a ser explorada como fonte primária da integração social; aliás, nisso consiste o agir comunicativo. Nessa perspectiva, consoante a função reguladora proporcionada pela força ilocucionária da ação de fala, temos a conexão entre as diversas alternativas de condutas fomentadas. Dessarte, criam-se padrões de comportamento, de modo a tornar menos

\footnotetext{
${ }^{24}$ HABERMAS, Jürgen. Mudança estrutural da esfera Pública, p. 36.
} 
BRAZ, Luciano da Silva. A razão dialética entre o direito e a condição humana: consciência, reconhecimento e emancipação. Revista Eletrônica Direito e Política, Programa de Pós-Graduação Stricto Sensu em Ciência Jurídica da UNIVALI, Itajaí, v.10, n.2, $1^{0}$ quadrimestre de 2015. Disponível em: www.univali.br/direitoepolitica - ISSN 1980-7791.

conflituosas as interações entre os sujeitos. É exatamente o redirecionamento das diversas alternativas de ação que possibilita o surgimento de uma ordem social, uma vez que esse redirecionamento reduz as alternativas a uma medida comum que passa a reduzir o risco do dissenso. Ademais, os atores, na qualidade de falantes e ouvintes, empenham-se em negociar interpretações comuns da situação e estabelecer entre si concordâncias com relação aos seus respectivos planos, por meio de processos de entendimento e pelo caminho de uma busca incondicionada de fins ilocucionários. Os planos de ação ficam, então, condicionados a um posicionamento a ser tomado pelos participantes, que consiste no ato de suspender o enfoque objetivador de um observador, bem como de um agente interessado, imediatamente, no próprio sucesso e, doravante, passam a adotar um enfoque performativo que corresponda ao de um falante que deseja entender-se como uma segunda pessoa sobre algo no mundo. Logo, as energias de ligação da linguagem podem ser mobilizadas para a coordenação de planos de fala, de tal modo que ofertas de atos de fala podem visar um efeito coordenador na ação, pois da resposta afirmativa do destinatário a uma oferta séria resultam obrigações que se tornam relevantes para as consequências da interação. ${ }^{25}$

No uso da linguagem como médium da socialização, no qual o agir comunicativo está referido, podemos visualizar a instrumentalidade (função) da ação de fala orientada pelo entendimento. A partir dessa instrumentalidade, o sujeito pode recorrer, adequadamente, a algumas pretensões de validade com relação à sua fala, na qual se dá o processo de formação do seu "eu", ou seja, dada a possibilidade real de atuação incutida no agir comunicativo, gradativamente, o sujeito da fala obterá autonomia e atuação interativa com os demais sujeitos, em que o agir comunicativo está inserido; participantes unem-se em torno da pretensa validade de suas ações de fala, ou constatam dissensos, os quais eles, de comum acordo, levarão em conta no decorrer da ação comunicativa. ${ }^{26}$

Do agir comunicativo, extrai-se uma conotação de que, mediante o uso da linguagem, os sujeitos findarão seus atos (pretensões de validade criticáveis) de fala no instante em que se fixar o entendimento formulado pelos mesmos ${ }^{27}$. Isso significa dizer que o entendimento passa a ser interpretado como um sistema ou processo de convencimento objetivado (racionalmente) intersubjetivamente pelos sujeitos, que coordena as atuações de todos os integrantes por meio da razão, de forma que, as ações de fala são entendidas como instrumentos para

\footnotetext{
${ }^{25}$ HABERMAS, Jürgen. Mudança estrutural da esfera Pública, p. 36.

${ }^{26}$ SILVA, Luciano Braz. O reconhecimento no Estado Democrático de Direito: perspectivas da filosofia de Habermas para efetividade da Democracia e dos Direitos Humanos. Revista Direito Práxis, Rio de Janeiro, v.4, n.7, 2013, p. 172.
}

27 HABERMAS, Jürgen. A constelação pós-nacional: Ensaios políticos, p. 432. 
BRAZ, Luciano da Silva. A razão dialética entre o direito e a condição humana: consciência, reconhecimento e emancipação. Revista Eletrônica Direito e Política, Programa de Pós-Graduação Stricto Sensu em Ciência Jurídica da UNIVALI, Itajaí, v.10, n.2, 10 quadrimestre de 2015. Disponível em: www.univali.br/direitoepolitica - ISSN 1980-7791.

atingi-lo; nesse sentido, o entendimento é o processo de obtenção de um acordo entre sujeitos linguística e interativamente competentes.

Finalmente, el concepto de acción comunicativa se refiere a la interacción de al menos dos sujetos capaces de lenguaje y de acción que (ya sea com médios verbales o con médios extraverbales) entablan una relación interpersonal. Los actores buscan entenderse sobre uma situación de acción para poder así coordinar de común acuerdos us planes de acción y con ello sus acciones. El concepto aqui central, el de interpretación, se refiere principalmente a La negociación de definiciones de la situación susceptibles de consenso. ${ }^{28}$

Nossas ações de fala situam-se em um mundo da vida compartilhado intersubjetivamente que, mediado por um pano de fundo consensual, nos possibilita um entendimento prévio sobre algo. Avalia Habermas que, em qualquer ação de fala, são levantadas pretensões criticáveis, que apontam para o reconhecimento intersubjetivo. Em sua leitura, Luiz Moreira levanta uma ressalva quanto à situação em que essa estrutura básica não se mostra suficiente para garantir a integração social, ao que, por conseguinte, surgirá a possibilidade do dissenso ou a respectiva necessidade de legitimar racionalmente nossas pretensões. Daí, quando a pergunta crítica pelo porquê de tal conduta se instala, é necessário que a busca dos fins ilocucionários de nossas ações de fala passe a coordená-las. Com a busca desses fins ilocucionários surge, então, no seio da interação entre os participantes do discurso, a pertinente possibilidade de resgate das pretensões de validade levantadas. Ou seja, em uma interação linguísticamente mediada,o ato de fala é portador de uma garantia de uma obrigação que há de ser resgatável à luz do melhor argumento.

Dada a distinção apresentada entre a idealidade da generalidade dos conceitos e dos significados e a idealidade dos conceitos de validade, verifica-se que tais distinções podem ser entendidas, por um lado, com o auxílio da estrutura de regras da linguagem em geral e, por outro lado, lançando mão dos pressupostos do uso da linguagem orientados pelo entendimento. Para Habermas, ambos os níveis de idealização estão atreladas na própria comunicação linguística e, desse modo, passam a intervir na constituição da realidade social de interações interligadas que se propagam no espaço e no tempo, seguindo o caminho do agir comunicativo. A idealidade da generalidade do significado delimita, demarcando os contextos do agir comunicativo, na medida em que os participantes não conseguem articular formalmente o propósito de entenderem-se sobre algo no mundo, nem atribuir às expressões utilizadas significados idênticos, caso não seja possível aos sujeitos de fala apoiarem-se numa linguagem comum.

${ }^{28}$ HABERMAS, Jürgen. A constelação pós-nacional: Ensaios políticos, p. 118. 
BRAZ, Luciano da Silva. A razão dialética entre o direito e a condição humana: consciência, reconhecimento e emancipação. Revista Eletrônica Direito e Política, Programa de Pós-Graduação Stricto Sensu em Ciência Jurídica da UNIVALI, Itajaí, v.10, n.2, $1^{0}$ quadrimestre de 2015. Disponível em: www.univali.br/direitoepolitica - ISSN 1980-7791.

Dessarte, os mal-entendidos só poderão ser descobertos como tais quando esta condição for preenchida. ${ }^{29}$

Compreende-se, assim, que a sociologia pode sim atribuir aos próprios sujeitos, que agem comunicativamente capacidades suficientes para superarem os estorvos de comunicação oriundos de simples mal-entendido, desde que, para tanto, a sociologia, desejosa de ter acesso ao seu campo de objetos, considere a tensão entre facticidade e validade, desde que os participantes da interação, cada qual atribua, reciprocamente, a tomada de consciência de seus atos, ou seja, devem presumir ser capazes de orientar seu agir por pretensões de validade. Entretanto, a partir do momento em que essa expectativa de racionalidade se revela falsa, os participantes - bem como os observadores sociológicos enquanto virtuais participantes - passam do enfoque performativo para o enfoque objetivador. Habermas chama-nos a atenção, ainda, para um outro grupo de problemas relacionado ao caráter de incondicionalidade das pretensões de validade, quando consideramos os pressupostos pretensiosos e contrafactuais. Assim:

Esse segundo nível de idealização determina, inclusive, a constituição da realidade social, de tal modo que todo acordo obtido comunicativamente e que torna possível à coordenação de ações, bem como estruturas complexas de interações e interligações de sequências de ações, mede-se pelo reconhecimento intersubjetivo de pretensões criticáveis, conferindo, destarte, uma função-chave ao funcionamento dos jogos de linguagem cotidianos e às tomadas de posição em termos de sim/não, que se apoiam em dupla negação. ${ }^{30}$

As tomadas de posições trazem consigo fatos sociais elaborados por elas mesmas. Nesses fatos sociais, encontram-se tensões que abarcam certo conteúdo ideal, pois reagem a pretensões de validade, as quais, para serem justificadas, pressupõem, necessariamente, o assentimento de um auditório idealmente ampliado. Com isso, tanto as normas como os enunciados - a validade que se quer seja reconhecida para ambas - transcendem, de acordo com seu sentido, espaços e tempos; de tal modo que, a pretensão atual é levantada sempre aqui e agora no interior de determinados contextos podendo ser aceita ou rejeitada ao que, por conseguinte, trará consequências para ação, gerando fato. Dessarte, a validade pretendida por nossos proferimentos e pelas práticas de nossa justificativa distingue-se da validade social dos 'standards' exercitados factualmente, das expectativas estabilizadas por meio da ameaça de sanções ou do simples costume. ${ }^{31}$

\footnotetext{
29 HABERMAS, Jürgen. Mudança estrutural da esfera Pública, p. 37-38.

30 HABERMAS, Jürgen. Mudança estrutural da esfera Pública, p. 38-39.

31 SILVA, Luciano Braz. O reconhecimento no Estado Democrático de Direito: perspectivas da filosofia de Habermas para efetividade da Democracia e dos Direitos Humanos, p. 165.
} 
BRAZ, Luciano da Silva. A razão dialética entre o direito e a condição humana: consciência, reconhecimento e emancipação. Revista Eletrônica Direito e Política, Programa de Pós-Graduação Stricto Sensu em Ciência Jurídica da UNIVALI, Itajaí, v.10, n.2, $1^{0}$ quadrimestre de 2015. Disponível em: www.univali.br/direitoepolitica - ISSN 1980-7791.

O caráter de incondicionalidade impresso nas pretensões de validade está enraizado nos processos de entendimento factuais. Enquanto pretensões, elas não se limitam a tempo ou espaço, transcendem qualquer contexto. Entretanto, devem ser colocadas e aceitas aqui e agora, caso contrário - considera Habermas - não poderão ser portadoras de um acordo capaz de coordenar a ação, pois não existe, para isso, um contexto zero.

\section{ESFERA PÚBLICA \& AUTODETERMINAÇÃO: ORDEM E PARADOXOS}

No Estado democrático de direito, o exercício do poder político regula-se a partir de duas codificações. Num primeiro momento, constata-se a necessidade de se entender como se dá o processamento institucionalizado dos problemas cogentes; num segundo instante, como se dá a mediação dos respectivos interesses, regrada segundo procedimentos claros, como efetivação de um sistema de direito. Depreende-se das constituições modernas uma ideia concebida sobre pressupostos do direito racional, do qual os cidadãos, por decisão própria, interligam-se a uma comunidade de jurisconsortes livres e iguais. Ora, a comunidade desses cidadãos, visando à estabilização das suas estruturas e as possíveis manutenções que se mostrarem necessárias, reclama uma constituição que assegure a todos eles um status que os iguale em direitos e garantias fundamentais. Esses direitos, garantidos pelas constituições, são identificados como direitos específicos dos quais os cidadãos, reciprocamente, reconhecem. Sendo assim, as constituições outorgarão a esses direitos convencionados e instituídos a partir dos diálogos democráticos - o caráter de validade e, consequentemente, os convívios dos cidadãos, regulados pelo direito positivo, possuirão legitimidade conferida pela própria constituição. Nesse sentido, não obstante o direito moderno - via sanção estatal - reconheça e fundamente relações de reconhecimento intersubjetivo, esses direitos (prima facie) asseguram a integridade dos respectivos sujeitos em particular, potencialmente violáveis. "Em última instância, trata-se da defesa dessas pessoas individuais do direito, mesmo quando a integridade do indivíduo - seja no direito, seja na moral - dependa da estrutura intacta das relações de reconhecimento mútuo" ${ }^{32}$. O filósofo alemão faz uma releitura dos pressupostos de validade do direito, tomando como campo de pesquisa o mundo da vida onde ocorrem os discursos, os diálogos interpelativos, o próprio exercício democrático; entende o filósofo que, dado às novas complexidades que surgiram nesses espaços, o direito reclama outras leituras que considere também novas perspectivas e interesses outrora inexistentes:

Mas, nas arenas políticas, quem se defronta são agentes coletivos, que discutem sobre objetivos coletivos e acerca da

32 HABERMAS, Jürgen. A inclusão do outro: estudos de teoria política. 3. ed. Tradução: Paulo AstorSoethe. São Paulo: Loyola. 2007, p. 237. 
BRAZ, Luciano da Silva. A razão dialética entre o direito e a condição humana: consciência, reconhecimento e emancipação. Revista Eletrônica Direito e Política, Programa de Pós-Graduação Stricto Sensu em Ciência Jurídica da UNIVALI, Itajaí, v.10, n.2, 10 quadrimestre de 2015. Disponível em: www.univali.br/direitoepolitica - ISSN 1980-7791.

distribuição dos bens coletivos. Apenas diante de um tribunal e no âmbito dum discurso jurídico é que se trata imediatamente de direitos individuais cobráveis por meio de ação judicial. Quanto ao direito vigente, também ele precisa ser interpretado de maneira diversa em face de novas necessidades e situações de interesse. Essa disputa acerca da interpretação e imposição de reivindicações historicamente irresolvidas é uma luta por direitos legítimos, nos quais estão implicados agentes coletivos que se defendem contra a desconsideração de sua dignidade. Nessa "luta por reconhecimento", segundo demonstrou A. Honneth, articulam-se experiências coletivas de integridade ferida. ${ }^{33}$

Assim, os discursos ocorridos nos espaços públicos democráticos podem conduzir à formulação de um sistema de direitos e de uma vontade política racional que se vincula a uma concepção de solidariedade cívica ou de patriotismo constitucional, que é necessário à implementação de instrumentos que tragam soluções aos emergentes conflitos decorrentes da convivência (interna e externa) nos contextos de diversidades culturais. Ao mesmo tempo, então, em que, os discursos proferidos nos espaços públicos destinados aos atos de fala constituem exercício efetivo da soberania popular, produzirão também concepções intersubjetivas de direitos fundamentais das quais se poderão pensar em condições e possibilidades de reconstruir a legitimidade dos Direitos Humanos com o objetivo de serem afirmados como direitos fundamentais universais. ${ }^{34}$ Vejamos que, em razão das conquista políticas liberais, bem como da socialdemocracia oriundas dos movimentos emancipatório e dos trabalhadores europeus, acreditou-se, então, numa teoria do direito que tornasse relevante algumas orientações de ordem individualistas. Essas ocorrências - lutas políticosociais de reconhecimento - objetivavam tão-somente suplantar a privação de direitos de grupos desprivilegiados e com isso, a fragmentação da sociedade em classes sociais; entretanto, as reivindicações daqueles grupos marginalizados que reclamavam para si chances iguais de vida no meio social, paulatinamente, ao se concretizar assumiram característica de universalização socioestatal dos direitos do cidadão. A filosofia de habermasiana aponta que, após a falência do socialismo de Estado, restou apenas essa perspectiva. O trabalho assalariado, a segurança, a justiça social e o bem-estar figuraram, prima facie, expectativas de direitos que promoveriam, de forma fundamentada, a promoção do status social

\footnotetext{
33 HABERMAS, Jürgen. A inclusão do outro: estudos de teoria política, p. 238.

34 POKER, José Geraldo A.B. A democracia e o problema da racionalidade. (orgs.) Clélia Aparecida Martins e José Geraldo Poker. O pensamento de Habermas em questão. Marilia: Oficina Universitária Unesp. 2008. p. 65.
} 
BRAZ, Luciano da Silva. A razão dialética entre o direito e a condição humana: consciência, reconhecimento e emancipação. Revista Eletrônica Direito e Política, Programa de Pós-Graduação Stricto Sensu em Ciência Jurídica da UNIVALI, Itajaí, v.10, n.2, $1^{0}$ quadrimestre de 2015. Disponível em: www.univali.br/direitoepolitica - ISSN 1980-7791.

que seria alcançado com o acréscimo desses direitos legalmente compartilhados e com a participação na vida política. ${ }^{35}$

No denominado mundo pós-moderno, as comunicações e as decisões que são tomadas, sejam em nível nacional ou internacional, demarcam seções próprias de tempo e espaço. Assuntos de repercussão nacional ou internacional ligados aos direitos fundamentais e aos direitos humanos, e à escolha de temas e contribuições que são discutidas sob a pressão político-social consomem energias próprias, exigem um investimento particular em termos de organização, implicam, além disso, custos em termos de decisão protelada ou perdida. Afirma Pozzoli ${ }^{36}$ que

Toda trajetória até então tida pela humanidade resultou em ter como princípio o respeito à vida, a continuidade da vida humana. Isto não pode ser negado. Assim, podemos ver o início de uma cultura indicadora do que hoje caracterizamos como dignidade da pessoa humana.

No que diz respeito às políticas de reivindicações, que buscam estabelecer igualdades de direitos, bem como o reconhecimento de identidades coletivas que visem a assegurar formas de vida culturais, por exemplo, feministas, minorias em sociedades multiculturais, povos que lutam por sua independência nacional ou regiões colonizadas no passado e que hoje reivindicam direitos e tratamentos igualitários. No cenário internacional, essas realidades dispares, diagnostificam uma realidade que parece contrariar a autocompreensão do Estado democrático de direito. Quando se discute políticas de reconhecimento de formas de vida e das tradições culturais sempre marginalizadas - ora no contexto de uma cultura majoritária, ora na sociedade mundial dominada por forças eurocêntricas ou do Atlântico Norte - necessariamente, não há que se falar também em garantias de status ou de sobrevivência? Com isso, não temos que apontar ao menos uma espécie de direitos coletivos dos quais faça romper a autocompreensão do Estado democrático de direito que herdamos moldada segundo direitos subjetivos, e, portanto de caráter liberal?. ${ }^{37}$

\subsection{Taylor, Honneth e Habermas: pressupostos teóricos para um reconhecimento}

As considerações de Amy Gutmann, que nos é apresentada por Habermas, aponta que o reconhecimento público pleno conta com duas formas de respeito,

35 SILVA, Luciano Braz. Estado democrático de direito, direitos humanos e democracia: perspectivas racional-discursivas no pensamento de Habermas. Revista Direito Mackenzie, São Paulo, v. 6, n. 2, 2014, p. 233.

${ }^{36}$ POZZOLI, Lafayette. Maritain e o Direito, p. 28.

37 HABERMAS, Jürgen. A inclusão do outro: estudos de teoria política, p. 239. 
BRAZ, Luciano da Silva. A razão dialética entre o direito e a condição humana: consciência, reconhecimento e emancipação. Revista Eletrônica Direito e Política, Programa de Pós-Graduação Stricto Sensu em Ciência Jurídica da UNIVALI, Itajaí, v.10, n.2, $1^{0}$ quadrimestre de 2015. Disponível em: www.univali.br/direitoepolitica - ISSN 1980-7791.

a saber: 1) o respeito pela identidade individual de cada indivíduo, o que significa dizer que esse respeito independe de sexo, raça ou procedência étnica; e 2) o respeito pelas formas de ação, pelas práticas e visões peculiares de mundo que gozam de prestígio junto aos integrantes de grupos desprivilegiados ou que estão intimamente ligados a essas pessoas. Nessa perspectiva, as exigências que são colocadas, objetivamente, não visam a estabelecer, em primeira linha, um status que asseguraria um padrão isonômico de condições sociais de vida; antes, o que se busca, em primeira mão, seria a defesa da integridade de formas de vida e tradições com as quais os membros de grupos discriminados - de modo próprio - identificam-se. O não reconhecimento de grupos sociais soa como uma dissonância cultural segregativa que marginaliza alguns grupos previamente rotulados; origina-se e mantém-se tão-somente com as condições ingeridas de demérito social, de modo que, o não reconhecimento cultural e o demérito social se fortalecem de maneira cumulativa. ${ }^{38}$

Charles Taylor considera que, dado o fato de que o asseguramento de identidades coletivas possa concorrer com o direito a liberdades subjetivas iguais - com o direito humano único e original, na concepção kantiana -, o que configuraria uma área de colisão entre ambos, certamente, a partir do caso concreto, dever-se-ia decidir sobre a precedência de um ou outro. A reflexão que segue exposta depõe em favor disso:

(...) já que a exigência 2 exige a consideração de particularidades das quais a exigência 1 parece abstrair, o princípio de tratamento equitativo deve alcançar validação nas políticas concorrentes - em uma política de respeito por todas as diferenças, por um lado, e em uma política de universalização de direitos subjetivos, por outro. Uma política deve compensar as desvantagens do universalismo uniformizante que a outra ocasiona ${ }^{39}$

Em seu ensaio seminal sobre o multiculturalismo, Taylor $^{40}$ entende que 0 reconhecimento não se trata de algo oriundo de uma cortesia, antes de tudo, trata-se da necessidade humana. Portanto, isso significa dizer que, pessoas e grupos podem - de certa forma - sofrerem danos consideráveis se a sociedade os identifica com imagens restritivas e depreciativas. Por meio das interações intersubjetivas (sejam elas agonísticas ou amistosas) e dialogais os sujeitos passam ser reconhecidos como tais, destarte, eles podem realizar suas originalidades insitas. A propósito, em um mundo que construiu uma imagem individualizada de identidade, consubstanciada pelo princípio de autonomia, uma

\footnotetext{
${ }^{38}$ SILVA, Luciano Braz. O reconhecimento no Estado Democrático de Direito: perspectivas da filosofia de Habermas para efetividade da Democracia e dos Direitos Humanos, p. 130.

39 HABERMAS, Jürgen. A inclusão do outro: estudos de teoria política, p. 240-241.

40 TAYLOR, C. The Politics of Recognition. In : GUTMANN, A. (ed.). Multiculturalism : Examining the Politics of Recognition. Princeton : Princeton University. 1994, p. 26.
} 
BRAZ, Luciano da Silva. A razão dialética entre o direito e a condição humana: consciência, reconhecimento e emancipação. Revista Eletrônica Direito e Política, Programa de Pós-Graduação Stricto Sensu em Ciência Jurídica da UNIVALI, Itajaí, v.10, n.2, $1^{0}$ quadrimestre de 2015. Disponível em: www.univali.br/direitoepolitica - ISSN 1980-7791.

vez que eu não sou verdadeiro comigo mesmo, consequentemente, eu passo a desconhecer a própria essência da minha identidade (da minha vida); consequentemente, eu passo a ignorar o que o ser humano significa para mim. ${ }^{41}$ Essa autonomia só pode ser construída em diálogos - em parte, externos e, em parte, internos - com os outros.

Taylor busca fundamentar seus argumentos teóricos sobre bases históricofilosóficas, e assim, retoma os alicerces valorativos que delineiam e estruturam a própria existência da sociedade. Desse modo, não seria absurdo pensar, por exemplo, que existem hierarquias valorativas tácitas que transcendem práticas cotidianas e instituições que se apresentam como imparciais, ou neutras, tais como o mercado e o Estado. Ora, vejamos que, a própria configuração dos sujeitos, atrelada às práxis do cotidiano, é regulada por princípios morais, ao que Taylor $^{42}$ denomina configurações. Uma "configuração incorpora um conjunto crucial de distinções qualitativas. Pensar, sentir, julgar no âmbito de tal configuração é funcionar com a sensação de que alguma ação ou modo de vida ou modo de sentir é incomparavelmente superior aos outros". Para Souza, Taylor está interessado, antes de tudo, "no componente avaliativo da constituição da identidade humana, na medida em que a auto interpretação dos sujeitos passa a ser percebida como momento constitutivo para a construção desta" ${ }^{43}$

Em uma espécie de arqueologia ligada à concepção de bem, Taylor pretende encontrar a autocompreensão dos atores com vistas a definição moral da época considerando essencialmente a cultura em que esses atores estão inseridos, o substrato das suas identidades ${ }^{44}$. Nessa perspectiva, na contemporaneidade, talvez o mais urgente e poderoso conjunto de exigências que reconhecemos como morais aponta o respeito à vida, à integridade, o bem-estar e mesmo à prosperidade dos outros. Desse modo, a figura da dignidade passa ser compreendida como a sendo a essência mátria do pano de fundo moral que rege as sociedades ocidentais contemporânea, superestimando a capacidade destas de implementar uma universalização de direitos que naturalize o valor da igualdade. ${ }^{45}$ Para o filósofo canadense, na modernidade, houve um declínio da sociedade hierarquicamente predeterminada, o que comprometeu significativamente a honra estamental em direção à dignidade geral. Enquanto a política da dignidade universal rechaçava as formas de discriminação, que eram bastante "cegas" com relação aos modos em que os cidadãos se diferem, a política da diferença, frequentemente, redefine a não-discriminação pretendendo

\footnotetext{
41 TAYLOR, C. The Politics of Recognition, p. 30.

42 TAYLOR, C. The Politics of Recognition, p. 35.

43 SOUZA, J. Charles Taylor e a teoria crítica do reconhecimento. Brasília: UnB, 2000, p. 99.

44 SOUZA, J. Uma teoria crítica do reconhecimento. São Paulo: Lua Nova, 2000, p. 137.

45 MATTOS, P. Recognition, between Justice and Identity. São Paulo: Lua Nova. 2004, p. 157.
} 
BRAZ, Luciano da Silva. A razão dialética entre o direito e a condição humana: consciência, reconhecimento e emancipação. Revista Eletrônica Direito e Política, Programa de Pós-Graduação Stricto Sensu em Ciência Jurídica da UNIVALI, Itajaí, v.10, n.2, $1^{0}$ quadrimestre de 2015. Disponível em: www.univali.br/direitoepolitica - ISSN 1980-7791.

como isso ver nas distinções a base do tratamento diferencial. Para Taylor ${ }^{46}$, a busca pelo reconhecimento envolve esses dois tipos de política, buscando no horizonte da consciência da igualdade do valor humano a valorização daquilo que cada um fez a partir dessa igualdade.

Para Habermas, tanto Taylor quanto Walzer contestam a ideia de uma suposta neutralidade ética no direito, resultando daí uma expectativa formada sobre os preceitos do Estado de Direito que tem como ideal a fomentação ativa de determinadas concepções do bem viver, caso isso se faça necessário. A partir das suas considerações, Taylor sugere um modelo alternativo que, de acordo com determinadas condições, é possível se pensar em garantias de status restritivas aos direitos fundamentais, desde que essas garantias possam assegurar a sobrevivência de formas de vida cultural, e que assegurem também o exercício de políticas ativamente empenhadas em gerar novos integrantes desses grupos, desde que dedicadas, por exemplo, a que as futuras gerações possam também identificar-se com seus precedentes. Nesse sentido, as compreensões de ordem política que envolvem deliberações, exercício e garantias de direitos fundamentais não estarão preocupadas tão-somente com os direitos inerentes às populações já existentes; antes, as reivindicações alcançarão os direitos das populações futuras. ${ }^{47}$ Assim, por meio de lutas simbólicas, os sujeitos negociam identidades, buscam reconhecimento próprio e social. Essas lutas, cada vez mais explícitas, transcendem interesses particulares, seus efeitos, tomam proporções gigantescas por via de protestos públicos que não buscam a simples tolerância ou condescendência, mas o respeito e a valorização do diferente.

Em primeiro lugar, é preciso observar - conforme aponta Habermas - que Taylor torna plausível sua tese da inconciliabilidade ao apresentar sua teoria dos direitos sob um enfoque seletivo de leitura ligado ao liberalismo. A teoria tayloriana, portanto, estabelece seu fundamento sobre o pressuposto de um status equitativo de liberdades de ação subjetivas, em forma de direitos fundamentais, para todos os jurisconsortes. Na hipótese da existência de casos controversos, o tribunal decidirá quais direitos cabem e a quem; assim, o princípio da equidade de direitos para todos "encontra validação tão-somente sob a forma de uma autonomia juridicamente apoiada, à disposição do uso de qualquer um que pretenda realizar seu projeto de vida pessoal". ${ }^{48}$ Essa interpretação atribuída ao sistema de direito é fortemente criticada por Habermas, que a caracteriza como sendo:

\footnotetext{
46 TAYLOR, C. The Politics of Recognition, p. 39.

47 SILVA, Luciano Braz. O reconhecimento no Estado Democrático de Direito: perspectivas da filosofia de Habermas para efetividade da Democracia e dos Direitos Humanos, p. 133.

48 HABERMAS, Jürgen. A inclusão do outro: estudos de teoria política, p. 242.
} 
BRAZ, Luciano da Silva. A razão dialética entre o direito e a condição humana: consciência, reconhecimento e emancipação. Revista Eletrônica Direito e Política, Programa de Pós-Graduação Stricto Sensu em Ciência Jurídica da UNIVALI, Itajaí, v.10, n.2, $1^{0}$ quadrimestre de 2015. Disponível em: www.univali.br/direitoepolitica - ISSN 1980-7791.

(...) paternalista, porque corta pela metade o conceito de autonomia. Ela não leva em consideração que os destinatários do direito só podem ganhar autonomia (em sentido kantiano) à medida que eles mesmos possam compreender-se como autores das leis às quais eles mesmos estão submetidos como sujeitos privados do direito. 0 liberalismo 1 ignora a equiprocedência das autonomias privada e pública. Não se trata aí apenas de uma complementação que permaneça externa à autonomia privada, mas sim de uma concatenação interna, ou seja, conceitualmente necessária. ${ }^{49}$

Habermas $^{50}$ entende que, enquanto aos sujeitos não estiverem assegurado o exercício comum e conjunto da sua autonomia enquanto cidadãos do Estado, consequentemente, 0 desfrute das liberdades subjetivas comuns estará embaraçado, ou seja, impedido. A orientação proposta pelo filósofo alemão vem fundamentada sobre a ideia impreterível de se estabelecer uma concatenação interna entre o Estado de Direito e a Democracia; consequentemente, teremos um sistema de direito que alcançará todos os modos de vida presentes no Estado, desde aquelas vidas circunscritas no centro urbano como aquelas postas à sua margem. Sendo assim, o sistema de direito poderá ouvir as múltiplas diferenças culturais existentes e, como tal, deverá assisti-las em suas diferenças devendo prestar-Ihes respostas quando por elas for invocado.

Em suas considerações Honneth aponta que por meio do reconhecimento intersubjetivo os sujeitos podem garantir realização plena das suas capacidades, bem como chegar a uma auto-relação marcada pela integridade, ou seja, os sujeitos, dadas suas interações, recebem certa modulações, destarte, só conseguirão formar uma auto-relação positiva caso possam se sentir reconhecidos por seus parceiros de interação.

A teoria de Honneth ${ }^{51}$ observa também substrato normativo presente nas relações sociais. Sua teoria parte do princípio de que o conflito é intrínseco, portanto necessário, tanto à formação da intersubjetividade como dos próprios sujeitos. Desse modo, conflito não é tomado apenas pela lógica da autoconservação dos indivíduos, como descrito no estado de natureza de Hobbes. Seu significado tem por preceito a conotação de uma luta moral, entendendo que a organização da sociedade, necessariamente, deve estar pautada por obrigações intersubjetivas. Honneth concatenua a idéia hegeliana com a psicologia social de George H. Mead.

\footnotetext{
49 HABERMAS, Jürgen. A inclusão do outro: estudos de teoria política, p. 242.

${ }^{50}$ HABERMAS, Jürgen. A inclusão do outro: estudos de teoria política, p. 243.

${ }^{51}$ HONNETH, A. Luta por reconhecimento: a gramática moral dos conflitos sociais. Trad: Luiz Repa. São Paulo: Ed. 34, 2003, p. 152.
} 
BRAZ, Luciano da Silva. A razão dialética entre o direito e a condição humana: consciência, reconhecimento e emancipação. Revista Eletrônica Direito e Política, Programa de Pós-Graduação Stricto Sensu em Ciência Jurídica da UNIVALI, Itajaí, v.10, n.2, $1^{0}$ quadrimestre de 2015. Disponível em: www.univali.br/direitoepolitica - ISSN 1980-7791.

Mead $^{52}$ direciona suas pretensões teóricas a partir de um horizonte intersubjetivista, defendendo a existência de um diálogo interno que toma os impulsos individuais e a cultura internalizada como objeto de pesquisa, e investiga a importância das normas morais nas relações humanas. Mead situa as interações sociais como campo onde ocorrem os conflitos entre o eu, a cultura e os outros. O teórico norte-americano defende a gênese social da identidade e vê a evolução moral da sociedade sempre atrelada à luta por reconhecimento forjada a partir de três tipos de relação: as primárias (reguladas pelo amor), as jurídicas (reconhecidas pela lei) e a esfera do trabalho onde está presente o valor do indivíduo com relação a coletividade.

A partir dessas premissas, Honneth ${ }^{53}$ sistematiza uma teoria do reconhecimento, descrevendo que são as lutas moralmente motivadas de grupos sociais, sua tentativa coletiva de estabelecer institucional e culturalmente formas ampliadas de reconhecimento recíproco, aquilo por meio do qual vem a se realizar a transformação normativamente gerida das sociedades. Hannet entende que o descaso, o desprezo social e político podem tornar impulsos que dinamizam lutas sociais, à medida que torna evidente que outros atores impedem a realização daquilo que se entende por bem viver, ou seja, se por um lado, o rebaixamento e a humilhação ameaçam identidades, por outro, eles estão na própria base da constituição de lutas por reconhecimento. Portanto, isso significa dizer, que toda reação emocional negativa que vai de par com a experiência de um desrespeito de pretensões de reconhecimento contém novamente em si a possibilidade de que a injustiça infligida ao sujeito se lhe revele em termos cognitivos e se torne o motivo da resistência política. ${ }^{54}$

$\mathrm{Na}$ concepção de Habermas, essa premissa constitui-se como condição vital sinequa non para que uma teoria dos direitos, entendida de maneira correta, venha a exigir, exatamente, e assegurar o direito ao exercício da política de reconhecimento que preserva a individualidade e a integridade do indivíduo até nos contextos vitais que conformam sua identidade ou a configuram. Nesse sentido, não é preciso que se formule um modelo oposto que corrija o viés individualista do sistema de direitos sob outros pontos de vista normativos; é preciso apenas que ocorra a realização coerente desse viés. Entende Habermas que os movimentos sociais e as lutas políticas são extremamente relevantes para concretização do reconhecimento. O autor compreende ser necessário que se crie e disponibilize competências jurídicas iguais das quais surgem espaços para liberdades de ação que podem ser utilizadas diferenciadamente, ou seja, não se fomenta a ideia de um formalismo irrestrito com vistas a uma igualdade factual de situações de vida ou de poder; antes, o multiculturalismo é visto de forma

\footnotetext{
52 MEAD, G. H. Espiritu, persona y sociedad. Ciudad de México : Paidós. 1993, p. 97.

${ }^{53}$ HONNETH, A. Luta por reconhecimento: a gramática moral dos conflitos sociais, p. 156.

${ }^{54}$ HONNETH, A. Luta por reconhecimento: a gramática moral dos conflitos sociais, p. 224.
} 
BRAZ, Luciano da Silva. A razão dialética entre o direito e a condição humana: consciência, reconhecimento e emancipação. Revista Eletrônica Direito e Política, Programa de Pós-Graduação Stricto Sensu em Ciência Jurídica da UNIVALI, Itajaí, v.10, n.2, $1^{0}$ quadrimestre de 2015. Disponível em: www.univali.br/direitoepolitica - ISSN 1980-7791.

salutar para a manutenção das identidades coletivas, seja no contexto de uma cultura majoritária ou em meio à comunidade dos povos. Contudo, observa o filósofo que alguns pressupostos factuais devem ser cumpridos para que "competências jurídicas sob condições de igualdade sejam distribuídas com equidade, caso se deseje evitar que o sentido normativo da igualdade de direitos se inverta por completo". ${ }^{55}$

Essa preocupação consiste exatamente em reconstruir a constituição cooriginária entre poder político e o direito, mostrando que, mediante essa relação, resulta um novo nível da tensão entre facticidade e validade, agora situada no próprio poder político. Nesse sentido, a questão da legitimação de um poder político estruturado na forma do Estado de Direito pode ser compreendida desde que, por intermédio da ótica do conceito de autonomia política dos cidadãos, fundamentado na teoria do discurso, se consiga diferenciar as figuras do poder comunicativo, produto do direito legítimo, e a do poder administrativo, responsável por imposições das leis. ${ }^{56}$ Assim, a contribuição do poder político para a função intrínseca do direito (estabilizar expectativas de comportamento) consiste na geração de uma certeza jurídica, que possibilita aos destinatários do direito calcular as consequências de seu comportamento e dos outros. As normas jurídicas, em termos gerais, devem regular as circunstâncias, as situações de fato, aplicando a sua subsunção de forma imparcial. Esses requisitos são compreendidos à luz de uma codificação (atividade jurisprudencial), que proporciona normas jurídicas altamente consistentes.

Com relação ao direito, sua contribuição à função intrínseca do poder administrativo (realizar fins coletivos) evidencia-se, especialmente, no desenvolvimento de normas secundárias, que, segundo Schumacher, não se tratam tão-somente daquelas normas "que conferem poder (e até criam) às instituições governamentais dotando-as de jurisdições especiais, como também normas organizacionais que estabelecem procedimentos para a existência e gestão administrativa ou judicial de programas jurídicos". Assim, a atividade do direito, sua função e aplicabilidade, atinge outras esferas que não somente a da atividade jurisprudência jurídica, mas alcança também a esfera das instituições de governo - procedimentos e competências - garantindo, assim, a autonomia privada e pública dos cidadãos. ${ }^{57}$

Numa releitura dos séculos XX e XIX, depreende-se que alguns agentes sociais sobretudo o feminismo, sob fortes oposições, precisaram empreender várias

${ }^{55}$ SILVA, Luciano Braz. A função do direito no mundo da vida: LINGUAGEM, EMANCIPAÇÃO E RECONHECIMENTO, p. 83.

${ }^{56}$ WERLE, Denílson L; SOARES, Mauro V. Política e direito: a questão da legitimidade do poder político no Estado Democrático de Direito. (Org.) Marcos Nobre, e Ricardo Terra. Direito e democracia: Um guia de leitura de Habermas. São Paulo: Malheiros. 2008, p. 130-131.

57 SCHUMACHER, Aluisio Almeida. "Comunicação e democracia: fundamentos pragmáticoformais e implicações jurídico-políticas da teoria da ação comunicativa", p. 246. 
BRAZ, Luciano da Silva. A razão dialética entre o direito e a condição humana: consciência, reconhecimento e emancipação. Revista Eletrônica Direito e Política, Programa de Pós-Graduação Stricto Sensu em Ciência Jurídica da UNIVALI, Itajaí, v.10, n.2, $1^{0}$ quadrimestre de 2015. Disponível em: www.univali.br/direitoepolitica - ISSN 1980-7791.

investidas para fazer valer seus objetivos legais e políticos. Inicialmente, a política liberal tencionou desacoplar conquistas de status e identidade de gênero, com seus reclames e protestos - conteúdo de seus ideários: as mulheres passaram a obter igualdades de chances na concorrência por postos de trabalho, prestígio social, nível de educação formal, poder político, etc. A igualdade formal que fora alcançada parcialmente pode agregar tão-somente uma fração da sociedade; com isso, evidenciou-se, ainda mais, as desigualdades de tratamento factual a que as mulheres estavam submetidas. Nesse contexto, políticas socioestatais, voltadas à implementação dos direitos (reconhecimentos) sociais ligados ao trabalho e a família, reagiram com regulamentações especiais; por exemplo, a maternidade e os encargos sociais, em caso de divórcio. Entrementes, a crítica feminista indignou-se contra as exigências liberais não resolvidas bem como contra os programas sociais implementados com êxito que trouxeram consequências ambivalentes, como os riscos de acidentes e infecções patológicas nos ambientes de trabalho, a presença excessiva de mulheres nos cargos de baixíssima remuneração laborativa, o bem-estar infanto-juvenil evidentemente problematizado, a crescente "feminização" da pobreza de modo geral, etc. ${ }^{58}$ Habermas aponta, ainda, um fator preponderante que corroborou diretamente para a implementação dos estereótipos de identidades de gênero: em áreas do direito feminista, o paternalismo socioestatal assume um sentido literal e, nesse sentido, tanto o poder legislativo e a própria jurisdição passam orientar-se conforme os modelos tradicionais de interpretação que existiam. A classificação dos papéis sexuais e das diferenças do gênero compõem as camadas elementares da autocompreensão cultural da sociedade, com isso, considera Habermas que

Só agora o feminismo radical toma consciência do caráter dessa autocompreensão, que se revela falível, profundamente questionável e carente de revisão. Ele insiste, e com razão, em que se devem esclarecer junto à opinião pública de caráter político, ou seja, em um debate público acerca da interpretação adequada das carências, os enfoques sob os quais as diferenças entre experiências e situações de vida de determinados grupos de homens e mulheres se tornam significativos para um uso das liberdades de ação em igualdades de chances. ${ }^{59}$

A partir dessas considerações, Habermas acredita ser possível demonstrar, de forma clara, a transformação da compreensão paradigmática do direito que se configura ora pelas liberdades subjetivas em prol das concorrências em particular, ora mediante reivindicações de benefícios, ideário do Estado de bemestar social. Com isso, obtemos uma concepção procedimental do direito, em

${ }^{58}$ HABERMAS, Jürgen. A inclusão do outro: estudos de teoria política, p. 244.

${ }^{59}$ HABERMAS, Jürgen. A inclusão do outro: estudos de teoria política, p. 245. 
BRAZ, Luciano da Silva. A razão dialética entre o direito e a condição humana: consciência, reconhecimento e emancipação. Revista Eletrônica Direito e Política, Programa de Pós-Graduação Stricto Sensu em Ciência Jurídica da UNIVALI, Itajaí, v.10, n.2, $1^{0}$ quadrimestre de 2015. Disponível em: www.univali.br/direitoepolitica - ISSN 1980-7791.

que o processo democrático, a um só tempo, pode assegurar a autonomia privada e pública. Devemos considerar - a partir dos debates públicos - os aspectos relevantes para o tratamento igualitário ou desigual de casos típicos isolados, caso se queira assegurar às mulheres uma organização particular e autônoma da própria vida condizente com seus direitos subjetivos. As perspectivas fomentadas pelas lentes liberais do sistema de direitos que não considera essas relações, evidentemente, não se manterão; a não ser no entendimento errôneo do universalismo dos direitos fundamentais como nivelamento abstrato de diferenças tanto culturais como sociais.

\section{BIOPOLÍTICA, CIDADANIA E RECONHECIMENTO}

Os fenômenos sociais que potencializam os sujeitos, as comunidades e as nações a lutarem por um reconhecimento, muito embora, na maioria dos casos, sejam homogêneos e ainda demonstrem características similares, como é o caso do feminismo, o multiculturalismo, o nacionalismo e a luta contra a herança eurocêntrica do colonialismo, ainda que possam demonstrar algumas semelhanças, não podem ser confundidos, dado o fato das peculiaridades essenciais. Vejamos que a semelhança nos parece evidente, pois tanto as mulheres, as minorias étnicas e culturais, assim como também, as nações e culturas, todas se defendem da opressão que é lançada, da marginalização e do desprezo nos quais são encerrados. A defesa desses atores sociais se constrói mediante lutas e manifestos incessantes de reconhecimento de identidades coletivas, seja no contexto de uma cultura majoritária, seja em meio à comunidade dos povos. Esses aguerridos manifestos sociais são movimentos que buscam sua emancipação própria voltada sempre aos seus ideários políticos coletivos definidos culturalmente. ${ }^{60}$ Destarte, a questão do reconhecimento não afeta tão-somente questões de ordem diretamente ligadas à dignidade humana, mas também considerações de ordem jurídica que comprometem diretamente carências da vida humana. Em suas palavras, Habermas ${ }^{61}$ aponta que:

Embora o feminismo não seja a causa de uma minoria, ele se volta contra uma cultura dominante que interpreta a relação dos gêneros de uma maneira assimétrica e desfavorável à igualdade de direitos. A diferença de situações de vida e experiências peculiares ao gênero não recebe consideração adequada, nem jurídica nem informalmente; tanto a autocompreensão cultural das mulheres quanto a contribuição que elas deram à cultura comum estão igualmente distantes de contar com o devido

${ }^{60}$ SILVA, Luciano Braz. A função do direito no mundo da vida: LINGUAGEM, EMANCIPAÇÃO E RECONHECIMENTO, p. 89.

${ }^{61}$ HABERMAS, Jürgen. A constelação pós-nacional: Ensaios políticos, p. 246. 
BRAZ, Luciano da Silva. A razão dialética entre o direito e a condição humana: consciência, reconhecimento e emancipação. Revista Eletrônica Direito e Política, Programa de Pós-Graduação Stricto Sensu em Ciência Jurídica da UNIVALI, Itajaí, v.10, n.2, $1^{0}$ quadrimestre de 2015. Disponível em: www.univali.br/direitoepolitica - ISSN 1980-7791.

reconhecimento; e, com as definições vigentes, as carências femininas mal podem ser articuladas de forma satisfatória.

A luta política por reconhecimento centra-se em discursos debatidos nos espaços públicos voltados à interpretação de interesses de realizações peculiares aos diferentes gêneros; à medida que logra êxito, essa luta modifica a identidade coletiva das mulheres e, por conseguinte, acarreta, também, algumas mudanças de relações entre os gêneros, afetando, assim, de forma imediata, a autocompreensão dos homens. Com isso, aqueles valores reconhecidos em escala na sociedade são levados para os debates discursais, de forma que, dado o caráter de relevância desses valores para sociedade, a consequência da problematização desses valores chega até as áreas centrais da vida privada e, portanto, afetam os limites estabelecidos entre as esferas pública e privada, a situação se difere quando se trata da luta das minorias étnicas e culturais pelo reconhecimento de sua identidade coletiva; já que esses movimentos de emancipação visam, também, à superação da divisão (ou separação) ilegítima da sociedade, a autocompreensão da cultura majoritária pode não sair ilesa. ${ }^{62}$ Nas sociedades multiculturais os movimentos de emancipação não representam, resumidamente, fenômenos unitários. Isso significa dizer que eles se diferenciam de acordo com as diversas situações; por exemplo, as minorias endógenas considera o autor - podem tornar-se conscientes de sua identidade ou, por conta da imigração, poderão surgir novas minorias, e, mesmo assim, esse fenômeno ocorrerá com as políticas culturais de alguns Estados que se autocompreendem como Estados de migração, cabendo, essa tarefa de emancipação também aos Estados, cuja autocompreensão nacional dependa de uma adaptação à integração de culturas estrangeiras. ${ }^{63}$

Outra distinção abordada na filosofia habermasiana diz respeito novo tipo de nacionalismo que trata daquelas populações que compartilham entre si um destino histórico comum. Essas populações identificam e organizam-se em grupos étnicos linguisticamente homogêneos e, como tal, desejam manter sua identidade não apenas como comunidades ascendentes comuns, mas também sob a forma de um povo que se organiza como Estado, possui autonomia política. $O$ modelo de movimentos nacionais, considerado por Habermas ${ }^{64}$ :

(...) quase sempre foi o Estado nacional constituído por via republicana, tal como surgiu da Revolução Francesa. A Itália e a Alemanha, em comparação com os Estados nacionais da primeira geração, foram chamadas "nações tardias". Outro contexto foi dado pelo período de descolonização após a Segunda Guerra Mundial. Outra constelação, por sua vez, é

62 SILVA, Luciano Braz. A função do direito no mundo da vida: LINGUAGEM, EMANCIPAÇÃO E RECONHECIMENTO, p. 90.

${ }^{63}$ HABERMAS, Jürgen. A inclusão do outro: estudos de teoria política, p. 247.

${ }^{64}$ HABERMAS, Jürgen. A constelação pós-nacional: Ensaios políticos, p. 246. 
BRAZ, Luciano da Silva. A razão dialética entre o direito e a condição humana: consciência, reconhecimento e emancipação. Revista Eletrônica Direito e Política, Programa de Pós-Graduação Stricto Sensu em Ciência Jurídica da UNIVALI, Itajaí, v.10, n.2, $1^{0}$ quadrimestre de 2015. Disponível em: www.univali.br/direitoepolitica - ISSN 1980-7791.

dada pela decadência de impérios como o Reino Otomano, a Áustria-Hungria ou a União Soviética.

Disso se distinguem algumas situações de minorias nacionais que surgiram em virtude da formação de Estados nacionais, por exemplo, os bascos, curdos e irlandeses do norte. Um caso especial identificado por Habermas é a fundação do Estado de Israel, sua instituição fôra em decorrência de movimentos nacionalreligiosos e dos horrores humanos ocorridos em Auschwitz, na região da Palestina, inicialmente de mandato inglês e reivindicado por árabes. ${ }^{65}$

Em nível internacional, a luta por reconhecimento surgiu em decorrência do eurocentrismo e do predomínio da cultura ocidental no campo político mundial, ambos vistos por Habermas ${ }^{66}$ como condições essenciais para uma luta por reconhecimento em nível internacional. O filósofo aponta a Guerra do Golfo como um fato que tornou consciente essa dimensão. A percepção daquilo que ocorrera, os motivos políticos, os interesses camuflados, se deram às "sombras de uma história colonial ainda presente, a intervenção dos aliados foi vista por massas religiosamente mobilizadas e também por intelectuais secularizados como abuso da identidade e autonomia do mundo arábico-islâmico". Os vestígios, as marcas indeléveis dessas lutas fracassadas de reconhecimento marcam, até hoje, as relações históricas (a economia, a política, a religião, as relações de direitos humanos, etc.) entre Ocidente e Oriente e, tanto mais, o relacionamento do Primeiro Mundo com o Terceiro, como antes era chamado.

Num outro plano mais elaborado, situam-se os discursos filosóficos em sentido estrito, que consideram, de sobremodo, os problemas já referidos e os toma como ponto de partida para descrever os problemas de ordem geral. Esses fenômenos prestam-se aos esclarecimentos e às considerações explícitas quanto à dificuldade do acordo mútuo intercultural; eles esclarecem a relação entre moral e eticidade, ou uma interligação entre significação e validação, e reacendem a velha questão sobre podermos transcender o contexto de nossa respectiva língua e cultura ou, ao contrário, todos os padrões de racionalidade estarão atrelados a determinadas imagens de mundo e determinadas tradições. ${ }^{67}$ Com suas palavras, Habermas ${ }^{68}$ aponta que

As esmagadoras evidências da fragmentação de sociedades multiculturais e da confusão linguística babilônica em meio a uma sociedade mundial mais que complexa parecem compelir-nos a concepção holística de linguagem e a concepção contextualísticas de imagens de mundo que soam

\footnotetext{
${ }^{65}$ HABERMAS, Jürgen. A inclusão do outro: estudos de teoria política, p. 248.

${ }^{66}$ HABERMAS, Jürgen. A inclusão do outro: estudos de teoria política, p. 249.

67 SILVA, Luciano Braz. A função do direito no mundo da vida: LINGUAGEM, EMANCIPAÇÃO E RECONHECIMENTO, p. 97.

${ }^{68}$ HABERMAS, Jürgen. A inclusão do outro: estudos de teoria política, p. 250.
} 
BRAZ, Luciano da Silva. A razão dialética entre o direito e a condição humana: consciência, reconhecimento e emancipação. Revista Eletrônica Direito e Política, Programa de Pós-Graduação Stricto Sensu em Ciência Jurídica da UNIVALI, Itajaí, v.10, n.2, $1^{0}$ quadrimestre de 2015. Disponível em: www.univali.br/direitoepolitica - ISSN 1980-7791.

céticas em face de tantas reivindicações universalistas, sejam elas de natureza cognitiva ou normativa.

O autor ainda nos mostra que o debate sobre a realidade, ramificado e aberto até há pouco tempo, é de vital importância tendo em vista que seus resultados trazem consequências que tocam diretamente as considerações apresentadas em torno dos conceitos de bom e justo com os quais lidamos ao investigar as condições de uma política do reconhecimento. Nesse sentido, uma sugestão apontada por Taylor, em si mesma, remete-se a outra coisa; ela está embasada - considera Habermas - no plano de referências do direito e da política.

Nesse sentido, o problema do direito ou direitos de minorias ofendidas e maltratadas passa a ser um problema de ordem jurídica e, como tal, deve ser resolvido. No Estado de Direito, decisões políticas não podem infringir normas do direito positivo, ou seja, as decisões políticas, para que sejam validas, deverão se servir das regulamentações do direito positivo para tornarem-se efetivas em sociedades complexas. Dessarte, o médium do direito aponta para uma estrutura artificial onde decisões normativas prévias se relacionam. Verificamos, portanto, que o direito moderno em sua estrutura é identificado como formal e se embasa na premissa de que tudo não seja explicitamente proibido e permitido. O direito moderno reconhece, individualmente, cada pessoa como sujeito portador de direitos subjetivos; nesse sentido, como titulares de uma categoria de direitos, esses mesmos sujeitos podem - valendo-se desses direitos - tutelar judicialmente, contra particulares ou até mesmo contra o Estado, direitos que Ihes subtraíram. Nas palavras de Habermas ${ }^{69}$, o direito moderno é identificado como

Um direito coercivo porque sanciona de maneira estatal e estende-se apenas ao comportamento legal ou conforme normas - ele pode, por exemplo, tornar livres as religiões, mas não pode prescrever nenhuma consciência moral. É um direito positivo porque retroage às decisões - modificáveis de um legislador político, e é, finalmente, um direito escrito por via procedimental, já que legitimado mediante um procedimento democrático.

O direito moderno - positivo - muito embora regule comportamentos legais, ainda assim, para sua validade, deve ser reconhecido como legítimo. Não obstante seu reconhecimento, respeito e obediência por todos, o direito moderno deve ser reconhecido de maneira que também possa ser cumprido a qualquer momento por seus destinatários, pelo simples respeito à lei. Para Habermas, uma ordem jurídica é definida como legítima quando assegura, de forma equitativa, a autonomia de todos os cidadãos. Esta autonomia estará concretamente constituída no instante em que destinatários do direito entenderem-se como seus autores e destinatários. Tais autores então, como

${ }^{69}$ HABERMAS, Jürgen. A inclusão do outro: estudos de teoria política, p. 250. 
BRAZ, Luciano da Silva. A razão dialética entre o direito e a condição humana: consciência, reconhecimento e emancipação. Revista Eletrônica Direito e Política, Programa de Pós-Graduação Stricto Sensu em Ciência Jurídica da UNIVALI, Itajaí, v.10, n.2, $1^{0}$ quadrimestre de 2015. Disponível em: www.univali.br/direitoepolitica - ISSN 1980-7791.

participantes do processo legislativo, serão livres tão-somente se esse processo estiver regrado por atos de fala discursivos e, necessariamente, democráticos, em que todos possam supor que as regras ora firmadas e, desse modo, mereçam concordância geral sancionada pela razão. Por entendimento, faz-se menção a um processo discursivo racional que leva os sujeitos ao convencimento objetivado entre as partes. ${ }^{70}$

A partir dessa formulação, o conceito tradicional de razão prática adquire um valor heurístico: ele se torna fio condutor para reconstrução do emaranhado dos discursos; consequentemente, a concepção normativa que interpreta o direito, mormente filiado à moral passa a ser recusado na filosofia habermasiana. 0 processo democrático deve ser institucionalizado juridicamente, o princípio da soberania dos povos exige, o devido respeito a direitos fundamentais sem os quais, simplesmente, não pode haver um direito legítimo. Nesse sentido, Habermas $^{71}$ fala, em primeira linha, do direito à liberdades de ações subjetivas iguais que, por sua vez, pressupõem defesas jurídicas individuais e abrangentes. Com a instituição do Estado de Direito e o reconhecimento dos direitos subjetivos dos indivíduos, há consequências salutares para o tratamento do problema da isonomia jurídica e do igual reconhecimento de grupos culturalmente definidos, ou seja, de coletividades que se distinguem de outras - seja pela tradição, forma de vida, proveniência étnica, etc.

\subsection{Dignidade humana, exercício político e emancipação}

Os fenômenos sociais que potencializam os sujeitos, as comunidades e as nações a lutarem por um reconhecimento, muito embora, na maioria dos casos, sejam homogêneos e ainda demonstrem características similares, como é o caso do feminismo, o multiculturalismo, o nacionalismo e a luta contra a herança eurocêntrica do colonialismo, ainda que possam demonstrar algumas semelhanças, não podem ser confundidos, dado o fato das peculiaridades essenciais. Vejamos que a semelhança nos parece evidente, pois tanto as mulheres, as minorias étnicas e culturais, assim como também, as nações e culturas, todas se defendem da opressão que é lançada, da marginalização e do desprezo nos quais são encerrados. A defesa desses atores sociais se constrói mediante lutas e manifestos incessantes de reconhecimento de identidades coletivas, seja no contexto de uma cultura majoritária, seja em meio à comunidade dos povos. Esses aguerridos manifestos sociais são movimentos que buscam sua emancipação própria voltada sempre aos seus ideários políticos

70 HABERMAS, Jürgen. Teoria de la acción comunicativa. Racionalidad de La acción y racionalización social. Trad. Manuel Jimenez Redondo. Tomo I. Madrid: Taurus, 1987, p. 368.

${ }^{71}$ HABERMAS, Jürgen. A inclusão do outro: estudos de teoria política, p. 251. 
BRAZ, Luciano da Silva. A razão dialética entre o direito e a condição humana: consciência, reconhecimento e emancipação. Revista Eletrônica Direito e Política, Programa de Pós-Graduação Stricto Sensu em Ciência Jurídica da UNIVALI, Itajaí, v.10, n.2, $1^{0}$ quadrimestre de 2015. Disponível em: www.univali.br/direitoepolitica - ISSN 1980-7791.

coletivos definidos culturalmente. ${ }^{72}$ Destarte, a questão do reconhecimento não afeta tão-somente questões de ordem diretamente ligadas à dignidade humana, mas também considerações de ordem jurídica que comprometem diretamente carências da vida humana. Em suas palavras, Habermas $^{73}$ aponta que:

Embora o feminismo não seja a causa de uma minoria, ele se volta contra uma cultura dominante que interpreta a relação dos gêneros de uma maneira assimétrica e desfavorável à igualdade de direitos. A diferença de situações de vida e experiências peculiares ao gênero não recebe consideração adequada, nem jurídica nem informalmente; tanto a autocompreensão cultural das mulheres quanto a contribuição que elas deram à cultura comum estão igualmente distantes de contar com o devido reconhecimento; e, com as definições vigentes, as carências femininas mal podem ser articuladas de forma satisfatória.

A luta política por reconhecimento centra-se em discursos debatidos nos espaços públicos voltados à interpretação de interesses de realizações peculiares aos diferentes gêneros; à medida que logra êxito, essa luta modifica a identidade coletiva das mulheres e, por conseguinte, acarreta, também, algumas mudanças de relações entre os gêneros, afetando, assim, de forma imediata, a autocompreensão dos homens. Com isso, aqueles valores reconhecidos em escala na sociedade são levados para os debates discursais, de forma que, dado - caráter de relevância desses valores para sociedade, a consequência da problematização desses valores chega até as áreas centrais da vida privada e, portanto, afetam os limites estabelecidos entre as esferas pública e privada, a situação se difere quando se trata da luta das minorias étnicas e culturais pelo reconhecimento de sua identidade coletiva; já que esses movimentos de emancipação visam, também, à superação da divisão (ou separação) ilegítima da sociedade, a autocompreensão da cultura majoritária pode não sair ilesa. ${ }^{74}$ Nas sociedades multiculturais os movimentos de emancipação não representam, resumidamente, fenômenos unitários. Isso significa dizer que eles se diferenciam de acordo com as diversas situações; por exemplo, as minorias endógenas considera o autor - podem tornar-se conscientes de sua identidade ou, por conta da imigração, poderão surgir novas minorias, e, mesmo assim, esse fenômeno ocorrerá com as políticas culturais de alguns Estados que se autocompreendem como Estados de migração, cabendo, essa tarefa de emancipação também aos

\footnotetext{
72 SILVA, Luciano Braz. A função do direito no mundo da vida: LINGUAGEM, EMANCIPAÇÃO E RECONHECIMENTO, p. 89.

73 HABERMAS, Jürgen. A constelação pós-nacional: Ensaios políticos, p. 246.

${ }^{74}$ SILVA, Luciano Braz. A função do direito no mundo da vida: LINGUAGEM, EMANCIPAÇÃO E RECONHECIMENTO, p. 90.
} 
BRAZ, Luciano da Silva. A razão dialética entre o direito e a condição humana: consciência, reconhecimento e emancipação. Revista Eletrônica Direito e Política, Programa de Pós-Graduação Stricto Sensu em Ciência Jurídica da UNIVALI, Itajaí, v.10, n.2, $1^{0}$ quadrimestre de 2015. Disponível em: www.univali.br/direitoepolitica - ISSN 1980-7791.

Estados, cuja autocompreensão nacional dependa de uma adaptação à integração de culturas estrangeiras. ${ }^{75}$

Outra distinção abordada na filosofia habermasiana diz respeito novo tipo de nacionalismo que trata daquelas populações que compartilham entre si um destino histórico comum. Essas populações identificam e organizam-se em grupos étnicos linguisticamente homogêneos e, como tal, desejam manter sua identidade não apenas como comunidades ascendentes comuns, mas também sob a forma de um povo que se organiza como Estado, possui autonomia política. $\mathrm{O}$ modelo de movimentos nacionais, considerado por Habermas ${ }^{76}$ :

(...) quase sempre foi o Estado nacional constituído por via republicana, tal como surgiu da Revolução Francesa. A Itália e a Alemanha, em comparação com os Estados nacionais da primeira geração, foram chamadas "nações tardias". Outro contexto foi dado pelo período de descolonização após a Segunda Guerra Mundial. Outra constelação, por sua vez, é dada pela decadência de impérios como o Reino Otomano, a Áustria-Hungria ou a União Soviética.

Disso se distinguem algumas situações de minorias nacionais que surgiram em virtude da formação de Estados nacionais, por exemplo, os bascos, curdos e irlandeses do norte. Um caso especial identificado por Habermas é a fundação do Estado de Israel, sua instituição fora em decorrência de movimentos nacionalreligiosos e dos horrores humanos ocorridos em Auschwitz, na região da Palestina, inicialmente de mandato inglês e reivindicado por árabes. ${ }^{77}$

Em nível internacional, a luta por reconhecimento surgiu em decorrência do eurocentrismo e do predomínio da cultura ocidental no campo político mundial, ambos vistos por Habermas ${ }^{78}$ como condições essenciais para uma luta por reconhecimento em nível internacional. O filósofo aponta a Guerra do Golfo como um fato que tornou consciente essa dimensão. A percepção daquilo que ocorrera, os motivos políticos, os interesses camuflados, se deram às "sombras de uma história colonial ainda presente, a intervenção dos aliados foi vista por massas religiosamente mobilizadas e também por intelectuais secularizados como abuso da identidade e autonomia do mundo arábico-islâmico". Os vestígios, as marcas indeléveis dessas lutas fracassadas de reconhecimento marcam, até hoje, as relações históricas (a economia, a política, a religião, as relações de direitos humanos, etc.) entre Ocidente e Oriente e, tanto mais, o relacionamento do Primeiro Mundo com o Terceiro, como antes era chamado.

\footnotetext{
75 HABERMAS, Jürgen. A inclusão do outro: estudos de teoria política, p. 247.

76 HABERMAS, Jürgen. A constelação pós-nacional: Ensaios políticos, p. 246.

77 HABERMAS, Jürgen. A inclusão do outro: estudos de teoria política, p. 248.

78 HABERMAS, Jürgen. A inclusão do outro: estudos de teoria política, p. 249.
} 
BRAZ, Luciano da Silva. A razão dialética entre o direito e a condição humana: consciência, reconhecimento e emancipação. Revista Eletrônica Direito e Política, Programa de Pós-Graduação Stricto Sensu em Ciência Jurídica da UNIVALI, Itajaí, v.10, n.2, $1^{0}$ quadrimestre de 2015. Disponível em: www.univali.br/direitoepolitica - ISSN 1980-7791.

No debate sobre political correctness, fenômeno que ocasionou, em primeiro lugar, um autoentendimento entre os intelectuais norte-americanos sobre o status da modernidade, o que, para os radicais, significa um avanço entusiasta rumo à pós-modernidade e à remoção de figuras de pensamento totalizadoras, para os tradicionais seria o sinal de uma crise que só poderá ser superada por um persistente regresso às tradições clássicas do ocidente. Num outro plano mais elaborado, situam-se os discursos filosóficos em sentido estrito, que consideram, de sobremodo, os problemas já referidos e os toma como ponto de partida para descrever os problemas de ordem geral. Esses fenômenos prestamse aos esclarecimentos e às considerações explícitas quanto à dificuldade do acordo mútuo intercultural; eles esclarecem a relação entre moral e eticidade, ou uma interligação entre significação e validação, e reacendem a velha questão sobre podermos transcender o contexto de nossa respectiva língua e cultura ou, ao contrário, todos os padrões de racionalidade estarão atrelados a determinadas imagens de mundo e determinadas tradições ${ }^{79}$. Com suas palavras, Habermas ${ }^{80}$ aponta que

As esmagadoras evidências da fragmentação de sociedades multiculturais e da confusão linguística babilônica em meio a uma sociedade mundial mais que complexa parecem compelir-nos a concepção holística de linguagem e a concepção contextualísticas de imagens de mundo que soam céticas em face de tantas reivindicações universalistas, sejam elas de natureza cognitiva ou normativa.

O autor ainda nos mostra que o debate sobre a realidade, ramificado e aberto até há pouco tempo, é de vital importância tendo em vista que seus resultados trazem consequências que tocam diretamente as considerações apresentadas em torno dos conceitos de bom e justo com os quais lidamos ao investigar as condições de uma política do reconhecimento. Nesse sentido, uma sugestão apontada por Taylor, em si mesma, remete-se a outra coisa; ela está embasada - considera Habermas - no plano de referências do direito e da política.

Nesse sentido, o problema do direito ou direitos de minorias ofendidas e maltratadas passa a ser um problema de ordem jurídica e, como tal, deve ser resolvido. No Estado de Direito, decisões políticas não podem infringir normas do direito positivo, ou seja, as decisões políticas, para que sejam validas, deverão se servir das regulamentações do direito positivo para tornarem-se efetivas em sociedades complexas. Dessarte, o médium do direito aponta para uma estrutura artificial onde decisões normativas prévias se relacionam. Verificamos, portanto, que o direito moderno em sua estrutura é identificado como formal e se embasa na premissa de que tudo não seja explicitamente proibido e permitido. O direito

${ }^{79}$ SILVA, Luciano Braz. A função do direito no mundo da vida: LINGUAGEM, EMANCIPAÇÃO E RECONHECIMENTO, p. 97.

${ }^{80}$ HABERMAS, Jürgen. A inclusão do outro: estudos de teoria política, p. 250. 
BRAZ, Luciano da Silva. A razão dialética entre o direito e a condição humana: consciência, reconhecimento e emancipação. Revista Eletrônica Direito e Política, Programa de Pós-Graduação Stricto Sensu em Ciência Jurídica da UNIVALI, Itajaí, v.10, n.2, 10 quadrimestre de 2015. Disponível em: www.univali.br/direitoepolitica - ISSN 1980-7791.

moderno reconhece, individualmente, cada pessoa como sujeito portador de direitos subjetivos; nesse sentido, como titulares de uma categoria de direitos, esses mesmos sujeitos podem - valendo-se desses direitos - tutelar judicialmente, contra particulares ou até mesmo contra o Estado, direitos que Ihes subtraíram. Nas palavras de Habermas ${ }^{81}$, o direito moderno é identificado como

Um direito coercivo porque sanciona de maneira estatal e estende-se apenas ao comportamento legal ou conforme normas - ele pode, por exemplo, tornar livres as religiões, mas não pode prescrever nenhuma consciência moral. É um direito positivo porque retroage às decisões - modificáveis de um legislador político, e é, finalmente, um direito escrito por via procedimental, já que legitimado mediante um procedimento democrático.

O direito moderno - positivo - muito embora regule comportamentos legais, ainda assim, para sua validade, deve ser reconhecido como legítimo. Não obstante seu reconhecimento, respeito e obediência por todos, o direito moderno deve ser reconhecido de maneira que também possa ser cumprido a qualquer momento por seus destinatários, pelo simples respeito à lei. Para Habermas, uma ordem jurídica é definida como legítima quando assegura, de forma equitativa, a autonomia de todos os cidadãos. Esta autonomia estará concretamente constituída no instante em que destinatários do direito entenderem-se como seus autores e destinatários. Tais autores então, como participantes do processo legislativo, serão livres tão-somente se esse processo estiver regrado por atos de fala discursivos e, necessariamente, democráticos, em que todos possam supor que as regras ora firmadas e, desse modo, mereçam concordância geral sancionada pela razão. Por entendimento, faz-se menção a um processo discursivo racional que leva os sujeitos ao convencimento objetivado entre as partes. Esse processo coordena as ações de fala de todos os participantes por meio da razão que vale como motivação e regularização, sendo que as ações de fala são utilizadas como meio para se chegar ao convencimento e, por conseguinte, ao consenso. Desse modo, entendimento é o "processo de obtenção de um acordo entre sujeitos linguística e inteiramente competentes" ${ }^{82}$ No núcleo da linguagem há, algumas estruturas básicas dominadas pelo sujeito em determinados momentos da vida. Enquanto sujeito, no processo de formação do indivíduo, a consciência é um dos atributos que ele recebe, ou seja, a capacidade reflexiva adquirida mediante suas ações no mundo, o que o torna capaz de concebê-lo individualmente ou, em outras palavras, de uma forma peculiar. Logo, por meio da linguagem, sua ação prioriza o discurso racional

\footnotetext{
${ }^{81}$ HABERMAS, Jürgen. A inclusão do outro: estudos de teoria política, p. 250.

82 HABERMAS, Jürgen. Teoria de la acción comunicativa. Racionalidad de La acción y racionalización social, p. 368.
} 
BRAZ, Luciano da Silva. A razão dialética entre o direito e a condição humana: consciência, reconhecimento e emancipação. Revista Eletrônica Direito e Política, Programa de Pós-Graduação Stricto Sensu em Ciência Jurídica da UNIVALI, Itajaí, v.10, n.2, $1^{0}$ quadrimestre de 2015. Disponível em: www.univali.br/direitoepolitica - ISSN 1980-7791.

como condição para se chegar à veracidade da fala de um sujeito e analisar se a fala é coerente ou não com a ação; nesse sentido, poderá convertê-la em normas revalidadas, compreendidas e aceitas por todos. A estrutura básica da ação comunicativa vincula-se, em geral, a três pretensões objetivas pelos integrantes do mundo da vida, a saber: 1) pretensão de verdade: que corresponde à pretensão de que o enunciado seja verdadeiro - essa pretensão refere-se a afirmações e acontecimentos oriundos do mundo objetivo; 2) pretensões de justiça: os atos de fala, necessariamente, devem estar em sintonia com o contexto normativo vigente - faz-se alusão ao mundo social ou ao mundo das normas legitimamente reguladas e, 3) pretensão de veracidade: ocorre quando a intenção expressa na fala do indivíduo corresponde a seu pensamento - trata-se, especificamente, do mundo subjetivo do indivíduo. ${ }^{83}$

A partir dessa formulação, o conceito tradicional de razão prática adquire um valor heurístico: ele se torna fio condutor para reconstrução do emaranhado dos discursos; consequentemente, a concepção normativa que interpreta o direito, mormente filiado à moral passa a ser recusado na filosofia habermasiana. 0 processo democrático deve ser institucionalizado juridicamente, o princípio da soberania dos povos exige, o devido respeito a direitos fundamentais sem os quais, simplesmente, não pode haver um direito legítimo. Nesse sentido, Habermas $^{84}$ fala, em primeira linha, do direito à liberdades de ações subjetivas iguais que, por sua vez, pressupõem defesas jurídicas individuais e abrangentes. Com a instituição do Estado de Direito e o reconhecimento dos direitos subjetivos dos indivíduos, há consequências salutares para o tratamento do problema da isonomia jurídica e do igual reconhecimento de grupos culturalmente definidos, ou seja, de coletividades que se distinguem de outras - seja pela tradição, forma de vida, proveniência étnica, etc.

\section{AUTONOMIA POLÍTICA, RAZÃO DISCURSIVA E SOBERANIA POPULAR}

A tensão existente entre a soberania popular e os direitos humanos não pode ser solucionada - segundo o pensamento de Habermas ${ }^{85}$ - de modo sério, com base na teoria política, ou seja, a teoria política está aquém das condições necessárias para equacionar essa tensão. O republicanismo, que remonta a Aristóteles e ao Humanismo político do Renascimento, sempre concedeu preferência à autonomia pública dos cidadãos em detrimento das liberdades não-políticas dos indivíduos privados. O liberalismo que se refere a Locke denunciou o perigo suscitado pelos atos da maioria tirânica e postulou a precedência dos direitos humanos com

83 PENITENTE, Luciana Aparecida de Araújo. Habermas e Mead: A linguagem como Médium de Socialização. (Orgs). Clélia Aparecida Martins e José Geraldo Poker. O pensamento de Habermas em questão. Marilia: Oficina Universitária Unesp, 2008, p. 99.

${ }^{84}$ HABERMAS, Jürgen. A inclusão do outro: estudos de teoria política, p. 251.

${ }^{85}$ HABERMAS, Jürgen. A constelação pós-nacional: Ensaios políticos, p. 146-147. 
BRAZ, Luciano da Silva. A razão dialética entre o direito e a condição humana: consciência, reconhecimento e emancipação. Revista Eletrônica Direito e Política, Programa de Pós-Graduação Stricto Sensu em Ciência Jurídica da UNIVALI, Itajaí, v.10, n.2, $1^{0}$ quadrimestre de 2015. Disponível em: www.univali.br/direitoepolitica - ISSN 1980-7791.

relação à vontade do povo. Desse modo, não há alarde algum quanto ao motivo pela qual as teorias do direito tenham dado uma dupla resposta às questões de legitimação, ou seja, por um lado faz-se referência ao princípio da soberania popular e, por outro, faz-se alusão ao domínio das leis garantido pelos direitos humanos. No que tange ao princípio da soberania popular, aponta-se para os direitos de comunicação e participação que asseguram autonomia pública dos cidadãos do Estado; e quanto ao domínio das leis, temos os direitos fundamentais clássicos que garantem a autonomia privada dos membros da sociedade civil. Nesse sentido, o direito - dado o seu caráter instrumental legitima-se como um meio para o asseguramento equânime da autonomia pública e privada. ${ }^{86} \mathrm{~A}$ partir dessas premissas, os direitos humanos passariam ser entendidos, portanto, sob dois anglos:

Em um caso, os direitos humanos deveriam a sua legitimidade ao resultado da autocompreensão ética e da autodeterminação soberana de uma coletividade política; no outro caso, eles deveriam construir limites legítimos, a partir deles mesmos, que vedassem à vontade soberana do povo a usurpação das esferas de liberdade subjetivas intocáveis. ${ }^{87}$

Na dialética entre liberalismo e democracia radical, fenômenos intensificados com a Revolução Francesa, a disputa se concentrava em torno do modo como a igualdade pode ser equacionada frente à liberdade, bem como a unidade com a pluralidade, o direito da maioria com o da minoria. Para os liberais a institucionalização jurídica das liberdades iguais devem vir em primeira mão, sendo descritas como direitos subjetivos. Para eles, os direitos humanos gozam de um primado normativo do qual a vontade do legislador democrático subjaz; os direitos humanos permanecem, assim, com status prima facie em relação à democracia e à constituição que divide os poderes. Por sua vez, Habermas ${ }^{88}$ considera, que o ponto em destaque desta apreciação consiste no vínculo estabelecido entre razão prática e vontade soberana, entre direitos humanos e democracia. Para que a razão legitimadora do poder não se anteponha mais à vontade soberana do povo, situando os direitos humanos num estado natural fictício, atribui-se à pratica de legislação autônoma uma estrutura racional peculiar, de tal forma que a vontade unida dos cidadãos só pode manifestar-se na forma de leis gerais e abstratas, é forçada per se a uma operação que exclui todos os interesses não generalizáveis, admitindo apenas as normatizações que garantem a todos iguais liberdades. O exercício da soberania popular garante, pois, os direitos humanos.

\footnotetext{
${ }^{86}$ HABERMAS, Jürgen. A inclusão do outro: estudos de teoria política, p. 297-298.

87 HABERMAS, Jürgen. A constelação pós-nacional: Ensaios políticos, p. 147.

${ }^{88}$ HABERMAS, Jürgen. Era das transições, p. 258-259.
} 
BRAZ, Luciano da Silva. A razão dialética entre o direito e a condição humana: consciência, reconhecimento e emancipação. Revista Eletrônica Direito e Política, Programa de Pós-Graduação Stricto Sensu em Ciência Jurídica da UNIVALI, Itajaí, v.10, n.2, $1^{0}$ quadrimestre de 2015. Disponível em: www.univali.br/direitoepolitica - ISSN 1980-7791.

Logo, para que intuição ganhe expressão correta, recomenda-se observar o procedimento democrático sob pontos de vistas da teoria dos discursos, que trazem consigo os fenômenos do mundo da vida circunscritos em meio ao pluralismo social e a visões de mundo, de forma a se conferir legitimidade ao processo de criação do direito. Habermas ${ }^{89}$, então, define como válidas tãosomente as regulamentações que contam com a concordância quiçá de todos os envolvidos participantes de um mesmo discurso racional. Tratando-se de discursos e negociações, que se referem ao espaço em que se pode formar uma vontade política racional, então a suposição de racionalidade que deve embasar o processo democrático tem necessariamente de apoiar em um arranjo comunicativo engenhoso. Logo, a elaboração desse procedimento significa que

A almejada coesão interna entre direitos humanos e soberania popular consiste, assim, em que a exigência de institucionalização jurídica de uma prática civil do uso público das liberdades comunicativas seja cumprida justamente por meio dos direitos humanos. Direitos humanos que possibilitam o exercício da soberania popular não se podem impingir de fora, como uma restrição.

Essa reflexão só elucida os direitos políticos do cidadão, isto é, os direitos de comunicação e de participação que asseguram o exercício da autonomia política e não os direitos humanos clássicos que garantem a autonomia privada dos cidadãos. Os direitos fundamentais que tratam das liberdades subjetivas iguais, bem como os direitos fundamentais que tratam do status de identidade nacional e a ampla proteção jurídica individual são direitos que trazem consigo valores intrínsecos e, dessa forma, cabe a cada cidadão desempenhar esforços para sua real garantia, para que, assim, possam alcançar os objetivos de sua vida privada em igualdade de condições (chances). ${ }^{90}$

Partindo do pressuposto de uma relação isonômica entre os cidadãos em, que todos, sejam igualmente livres, devem, reciprocamente, conceder uns aos outros, quais espécies de direitos fundamentais, se quiserem regulamentar a sua vida em comum por meio do direito positivo? Neste ponto, Habermas ${ }^{91}$ parte de um princípio em que todos os sujeitos de atos de fala devem arguir a legitimidade daquelas regulamentações com as quais todos os possivelmente atingidos concordariam como participantes de um discurso. Nos discursos, os participantes, à medida que formulam seus argumentos contrafactuais, procuram convencer uns aos outros e, nesse sentido, consequentemente, chegaram num ponto comum (convenção); já nas negociações, os sujeitos buscam tão-somente equacionar seus interesses particulares. Logo se, tais discussões e negociações

\footnotetext{
89 HABERMAS, Jürgen. A inclusão do outro: estudos de teoria política, p. 300.

${ }^{90}$ HABERMAS, Jürgen. A inclusão do outro: estudos de teoria política, p. 300.

${ }^{91}$ HABERMAS, Jürgen. A constelação pós-nacional: Ensaios políticos, p. 148.
} 
BRAZ, Luciano da Silva. A razão dialética entre o direito e a condição humana: consciência, reconhecimento e emancipação. Revista Eletrônica Direito e Política, Programa de Pós-Graduação Stricto Sensu em Ciência Jurídica da UNIVALI, Itajaí, v.10, n.2, 10 quadrimestre de 2015. Disponível em: www.univali.br/direitoepolitica - ISSN 1980-7791.

constituem o campo em que a vontade política racional pode se formar, a suposição de resultados legítimos, que devem fundamentar o procedimento democrático, deve se apoiar, em última instância, num arranjo comunicativo. 0 nexo interno que se imagina estar acoplado entre os direitos humanos e a soberania popular consiste, portanto,

(...) no fato de que os direitos humanos institucionalizam as condições de comunicação para a formação da vontade política racional. Direitos que possibilitam o exercício da soberania popular não podem ser impostos a essa práxis como limitações de fora. Esse raciocínio é evidente de modo imediato apenas para os direitos políticos civis, ou seja, para os direitos de comunicação e à participação, mas não para os direitos clássicos à liberdade que garantem a autonomia privada dos cidadãos.

Contudo, quando se busca decidir se é possível (ou não) a institucionalizar, sob forma de direito político dos cidadãos, os pressupostos de comunicação dos quais os sujeitos de atos de fala julgam se é legítimo o direito que eles firmam à luz do princípio discursivo, nesse ponto, o código jurídico precisa estar como tal à disposição. Destarte, faz-se necessário que se crie um status dos sujeitos de direito que pertençam, como portadores de direitos subjetivos, a uma associação voluntária de jurisconsortes e que, efetivamente, façam valer, por meio do ordenamento legal, suas respectivas reivindicações jurídicas. Portanto, uma vez que a autonomia privada venha a ser mitigada, não há que se falar em direito algum e, no mesmo sentido, não existindo direitos fundamentais que asseguram a autonomia privada dos cidadãos, consequentemente, não haverá também o medium para institucionalização jurídica das condições que garantem o exercício da autonomia pública no desempenhar do seu papel de cidadãos do Estado. ${ }^{92} \mathrm{~A}$ partir dessas considerações, entende-se que, pelo fato de os cidadãos só poderem fazer uso adequado de sua autonomia pública desde que estejam no uso pleno da sua autonomia, ou seja, sejam independentes o bastante em razão duma autonomia privada equanimemente assegurada, entretanto, os mesmo só poderão chegar a uma regulamentação capaz de formular um consenso, desde que façam, adequadamente, o uso de suas autonomias políticas, enquanto cidadãos do Estado; é por isso que, os direitos fundamentais liberais e políticos são indivisíveis.

\section{CONSIDERAÇÕES FINAIS}

Resumidamente, já verificamos em linhas supra, que a ideia do Estado de Direito sustentado pelo direito legitimamente instituído exige do poder público uma organização quanto aos seus atos. Nesse sentido, o poder político deve espelhar

\footnotetext{
${ }^{92}$ HABERMAS, Jürgen. A inclusão do outro: estudos de teoria política, p. 301.
} 
BRAZ, Luciano da Silva. A razão dialética entre o direito e a condição humana: consciência, reconhecimento e emancipação. Revista Eletrônica Direito e Política, Programa de Pós-Graduação Stricto Sensu em Ciência Jurídica da UNIVALI, Itajaí, v.10, n.2, $1^{0}$ quadrimestre de 2015. Disponível em: www.univali.br/direitoepolitica - ISSN 1980-7791.

em seus atos a legitimidade reconhecida na instituição do próprio direito. Simultaneamente, teremos entre o código do direito e o código do poder uma mútua complementação, com o fim de preencher suas respectivas funções. Nessa linha de entendimento, observamos que a interligação complexa entre direito vinculante e poder político abre possibilidade à instrumentalização do direito, no sentido de seu emprego estratégico. Sendo assim, no Estado de Direito, qualquer uso publicamente autorizado do poder reclama uma legitimidade conferida nos termos do direito legitimamente instituído.

No sistema da administração pública, encontra-se um poder que the fora conferido para o exercício das suas prerrogativas (licença, autorização, concessão, permissão, etc.) enquanto administração pública. Esse poder precisa regenerar-se a cada passo a partir do poder comunicativo. Dessa forma, o direito não é visto tão-somente como algo constitutivo para o código do poder que dirige o processo de administração, constatando-se que o direito forma, portanto e simultaneamente, o médium para a transformação do poder comunicativo em administrativo. Essas ligações conceituais de Habermas são trabalhadas a partir de duas perspectivas: na primeira, enfatiza o princípio da soberania popular para introduzir os princípios do Estado de Direito; na segunda, procura desenvolver esses princípios na perspectiva da institucionalização jurídica da rede que abarca discursos e negociações.

No princípio da soberania popular, em que se concebe a ideia de que todo poder do Estado emana do povo, o direito subjetivo à participação com oportunidades iguais na formação democrática da vontade, consente com a possibilidade jurídico-objetiva de uma prática institucionalizada de autodeterminação dos cidadãos pelo uso da razão comunicativa. Uma vez reconhecida essa prática por todos, como um processo de resolução de problemas sociais e políticos, sua força de legitimação tem como fundamento um processo democrático destinado a garantir um tratamento racional para os problemas arrostados. Da lógica dos discursos, resulta também o princípio do pluralismo político que se faz expressar dentro e fora dos corpos representativos. Nesse sentido, o princípio da soberania popular exige uma estruturação discursiva de arenas públicas nas quais sistemas de comunicação anônimos destacam-se do nível concreto de simples interações. Ora, essa informalidade de sistemas de comunicação anônimos visam a complementar a formação da opinião e da vontade parlamentar não preenchida integralmente. As arenas públicas devem sua efetividade na formação dos discursos inerentes aos direitos fundamentais, sem os quais não se pode proporcionar aos atores o fluxo livre de opiniões, pretensões de validade e tomadas de posições.

Esses direitos, reciprocamente atribuídos pelos cidadãos numa dimensão horizontal (cidadão - a - cidadão), precisam ser ainda mais estendidos, a partir do momento em que se constitui um poder executivo, à dimensão vertical entre as relações dos cidadãos com o Estado. Esses direitos, interpretados como 
BRAZ, Luciano da Silva. A razão dialética entre o direito e a condição humana: consciência, reconhecimento e emancipação. Revista Eletrônica Direito e Política, Programa de Pós-Graduação Stricto Sensu em Ciência Jurídica da UNIVALI, Itajaí, v.10, n.2, $1^{0}$ quadrimestre de 2015. Disponível em: www.univali.br/direitoepolitica - ISSN 1980-7791.

"liberais", formam - num sentido mais estrito do ponto de vista histórico - o núcleo das declarações dos direitos humanos. A separação entre Estado e sociedade, busca ressaltar uma garantia jurídica de forma a instaurar uma autonomia social, e assim conferir a cada cidadão iguais oportunidades ao uso de seus direitos de participação política e de comunicação. Esse princípio exige a instauração de uma sociedade civil que direcione - democraticamente - as relações de associações e a própria cultura política desenvolvida. O Estado não pode ser confundido com a sociedade, exercendo papéis ou participando de negociações que colocariam ambos no mesmo lugar. A sociedade civil, por si só, precisa equalizar e neutralizar a divisão desigual de posições sociais de poder e dos potenciais de poder daí derivados, objetivando, com isso, esperar que o poder social possa impor-se na medida em que possibilita, sem restringir, o exercício da autonomia dos cidadãos. Com a expressão poder social, Habermas busca apontar a possibilidade de um ator impor interesses próprios na esfera das relações sociais, mesmo que esses interesses possam resistir a interesses alheios.

\section{REFERÊNCIAS DAS FONTES CITADAS}

CHAMON J. Lúcio Antonio. Filosofia do direito na alta modernidade: Incursões teóricas em Kelsen, Luhmann e Habermas. Rio de Janeiro: Lúmen Júris, 2005.

DURÃO, Aylton Barbieri. A tensão interna entre facticidade e validade no direito segundo Habermas. (Org), MARTINS, Clélia Aparecida, e POKER, José Geraldo. 0 pensamento de Habermas em questão. Marília: Oficina Universitária Unesp, 2008.

HABERMAS, Jürgen. A inclusão do outro: estudos de teoria política. 3. ed. Tradução: Paulo AstorSoethe. São Paulo: Loyola. 2007.

HABERMAS, Jürgen. Mudança estrutural da esfera Pública. 2. ed. Tradução: Flávio R. Kothe. Rio de Janeiro: Tempo Brasileiro. 2003.

HABERMAS, Jürgen. Direito e democracia: entre facticidade e validade. I. 2 . ed. Tradução: Flávio Beno Siebeneichler. Rio de Janeiro: Tempo Brasileiro. 2003.

HABERMAS, Jürgen. Direito e democracia: entre facticidade e validade. II. 2. ed. Tradução: Flávio Beno Siebeneichler. Rio de Janeiro: Tempo Brasileiro. 2003.

HABERMAS, Jürgen. Era das transições. Tradução: Flávio BenoSiebeneichler. Rio de Janeiro: Tempo Brasileiro, 2003.

HABERMAS, Jürgen. A constelação pós-nacional: Ensaios políticos. Tradução: Márcio Seligmann Silva. São Paulo: Littera Mundi, 2001. 
BRAZ, Luciano da Silva. A razão dialética entre o direito e a condição humana: consciência, reconhecimento e emancipação. Revista Eletrônica Direito e Política, Programa de Pós-Graduação Stricto Sensu em Ciência Jurídica da UNIVALI, Itajaí, v.10, n.2, $1^{0}$ quadrimestre de 2015. Disponível em: www.univali.br/direitoepolitica - ISSN 1980-7791.

HABERMAS, Jürgen. O discurso filosófico da modernidade. Tradução: Ana Maria Bernado Et all. Lisboa: Dom quixote, 1990.

HABERMAS, Jürgen. Pensamento pós-metafísico: estudos filosóficos. Trad. Flávio BenoSiebeneichler. Rio de Janeiro: Tempo Brasileiro, 1990.

HABERMAS, Jürgen. Teoria de la acción comunicativa. Racionalidad de La acción y racionalización social. Trad. Manuel Jimenez Redondo. Tomo I. Madrid: Taurus, 1987.

HONNETH, A. Luta por reconhecimento: a gramática moral dos conflitos sociais. Trad: Luiz Repa. São Paulo: Ed. 34, 2003.

MATTOS, P. Recognition, between Justice and Identity. São Paulo: Lua Nova. 2004.

MEAD, G. H. Espiritu, persona y sociedad. Ciudad de México : Paidós. 1993.

MOREIRA, Luiz. Fundamentação do direito em Habermas. Belo Horizonte: Mandamentos, 1999.

PENITENTE, Luciana Aparecida de Araújo. Habermas e Mead: A linguagem como Médium de Socialização. (Orgs). Clélia Aparecida Martins e José Geraldo Poker. O pensamento de Habermas em questão. Marilia: Oficina Universitária Unesp, 2008.

PIZZI, Jovino. Desafios Éticos e Políticos da Cidadania. Ensaios de Ética e Filosofia Política. Ijuí: Unijuí. 2006.

POZZOLI, Lafayette. Maritain e o Direito. São Paulo: Loyola. 2001.

POKER, José Geraldo A.B. A democracia e o problema da racionalidade. (orgs.) Clélia Aparecida Martins e José Geraldo Poker. O pensamento de Habermas em questão. Marilia: Oficina Universitária Unesp. 2008.

SCHUMACHER, Aluisio Almeida. "Comunicação e democracia: fundamentos pragmático-formais e implicações jurídico-políticas da teoria da ação comunicativa". 2000. 245 f. Tese (Doutorado em Ciências Política). Departamento de Ciências Política do Instituto de Filosofia e Ciências Humanas da Universidade Estadual de Campinas. Campinas, 2000.

SILVA, Luciano Braz. Estado democrático de direito, direitos humanos e democracia: perspectivas racional-discursivas no pensamento de Habermas. Revista Direito Mackenzie, São Paulo, v. 6, n. 2, 2014, p. 230-250.

SILVA, Luciano Braz. Legitimidade do poder e exercício político: facticidade e validade do direito. Perpectivas para uma análise normativa e instrumental. EM TEMPO - Marília - v. 12 - 2013, p. 219-237. 
BRAZ, Luciano da Silva. A razão dialética entre o direito e a condição humana: consciência, reconhecimento e emancipação. Revista Eletrônica Direito e Política, Programa de Pós-Graduação Stricto Sensu em Ciência Jurídica da UNIVALI, Itajaí, v.10, n.2, $1^{0}$ quadrimestre de 2015. Disponível em: www.univali.br/direitoepolitica - ISSN 1980-7791.

SILVA, Luciano Braz. A função do direito no mundo da vida: LINGUAGEM, EMANCIPAÇÃO E RECONHECIMENTO. Revista Direito e Liberdade - Santa Catarina - v. 15, n. 3, 2013, p. 71-95.

SILVA, Luciano Braz. O reconhecimento no Estado Democrático de Direito: perspectivas da filosofia de Habermas para efetividade da Democracia e dos Direitos Humanos. Revista Direito Práxis, Rio de Janeiro, v.4, n.7, 2013, p. 122152.

SOUZA, J. Charles Taylor e a teoria crítica do reconhecimento. Brasília: UnB, 2000.

SOUZA, J. Uma teoria crítica do reconhecimento. São Paulo: Lua Nova, 2000.

TAYLOR, C. The Politics of Recognition. In : GUTMANN, A. (ed.). Multiculturalism : Examining the Politics of Recognition. Princeton : Princeton University. 1994

TAYLOR, C. As fontes do self: a construção da identidade moderna. Tradução de Adail U. Sobral; Dinah de A. Azevedo. São Paulo: Loyola, 1997.

WERLE, Denílson L; SOARES, Mauro V. Política e direito: a questão da legitimidade do poder político no Estado Democrático de Direito. (Org.) Marcos Nobre, e Ricardo Terra. Direito e democracia: Um guia de leitura de Habermas. São Paulo: Malheiros. 2008.

Submetido em: Março/2015

Aprovado em: Abril/2015 